\title{
The Predictability of International Real Estate Markets, Exchange Rate Risks and Diversification Consequences
}

\author{
Crocker H. Liu, New York University \\ Jianping Mei, New York University
}

International real estate related securities are investigated to see whether they offer any incremental diversification benefits -over foreign stocks using mean-variance analysis together with a multifactor latent variable model. Diversification benefits are found to be primarily driven by unanticipated returns which are partially driven by changes in exchange rate risk. Although exchange rate risk accounts for a larger portion of the return fluctuation in real estate related securities relative to common stocks, international real estate securities provide some incremental diversification benefits over common stocks even if currency risks are hedged.

Recent evidence suggests that returns for United States real estate securities and stocks are not only predictable but also that these returns tend to move in tandem. ${ }^{1}$ While some controversy exists on whether these findings are also applicable on an international basis for stock returns, little (if any) research exists on either the predictability or co-movement of international real estate related securities. ${ }^{2}$ The purpose of this study is to investigate the degree to which returns on international stocks and real estate related securities are predictable and exhibit systematic co-movement. The role of this co-movement on international portfolio diversification is then assessed. If returns are fairly

\footnotetext{
${ }^{1}$ See, for example, Fama and Schwert (1977), Chen, Roll and Ross (1986), Keim and Stambaugh (1986), Campbell (1987), Fama, French $(1988,1989)$ and Campbell and Hamao (1992). These studies find that the dividend yield on the stock market, the January effect, the return on Treasury bills and the long-term yield spread are useful in predicting excess stock returns among other variables. Liu and Mei $(1992,1993)$ also find these factors in addition to the cap rate can help predict excess real estate returns. Liu and Mei further find that excess returns on real estate are more predictable than stocks.

${ }^{2}$ Both Stehle (1977) and Errunza and Losq (1985) cannot reject the proposition that a common factor(s) affects returns on international stocks. Jorion and Schwartz (1986) in contrast, find that different factors may impact on different stock markets as a result of statutory investment barriers. Recently, Campbell and Hamao (1992) find that common factors influence returns on U.S. and Japanese stocks and that these returns are predictable.
} 
predictable and is the result of the integration of returns on stock and real estate related securities among markets where integration is evidenced by common factors that are responsible for the systematic comovement of returns, then the construction of efficient portfolios is affected.

A related issue is whether it pays to use international real estate related securities if a portfolio already includes international stocks of each country and if all the markets for stocks and real estate securities are integrated. The extent to which own country real estate related securities offer incremental benefits over and above that of stocks in each country has not been studied. Some diversification studies involving international real estate have used returns on direct real estate investment which have different characteristics from that of real estate related securities. Alternatively, other studies have used an international real estate index which provides few insights on portfolio construction from a micro-perspective (e.g., mixed asset), inter-country portfolio construction. Of the few papers on international real estate diversification, Ziobrowski and Curcio (1991) find that U.S. real estate did not offer U.K. and Japanese investors any significant incremental diversification advantages over own country real estate due to higher riskiness of U.S. real estate when returns are denominated in foreign currency. In contrast to this, Asabere, Kleiman and McGowan (1991) conclude that international real estate should improve portfolio efficiency for U.S. investors given a weak positive correlation with U.S. real estate investment trust (REIT) returns. Asabere et al. further find that international real estate equity securities have a higher risk and return relative to U.S. REITs. A partial reason for the conflicting results is that the former study employs direct real estate investment whereas the latter study uses the Morgan-Stanley index of international real estate securities. In addition, different methodologies are also used. In exploring this issue, the impact of exchange rate risk is also considered since prior studies have shown that currency risk is a dominant factor. Consideration is also given to whether the results here are robust to hedged versus unhedged returns. However, settlement costs and other transaction costs are not included in the analysis of hedging currency risk although the consequences of these costs on portfolio risk and return are discussed. ${ }^{3}$

This study has several distinguishing features. First, monthly returns on real estate related securities for six countries are used. Returns on foreign property trusts are utilized for a more direct comparison with portfolio diversification studies involving U.S. REITs except where no trusts exist. In these cases, property companies are employed to get some sense of incremental diversification

\footnotetext{
${ }^{3}$ Most studies on international stocks and real estate either ignore exchange rate fluctuations or alternatively adjust returns for currency on a periodic basis. Moreover, Worzala (1995) observes in a survey of institutional investors with respect to international investments that "...few of these international investors indicate hedging as one of their basic strategies." As such, this study is guilty of the same sins of omission.
} 
benefits. Second, only one factor is necessary in accounting for the time-variation of expected returns across different countries. This implies that international real estate securities are integrated with international stocks because one factor can account for the movement of the expected returns of all assets. This result holds regardless of whether exchange risk is hedged. However, the unexpected portion of returns is quite large and accounts for most of the diversification benefits. Also, changes in currency risk account in part for movements in unanticipated returns. This phenomenon is more pronounced for real estate related securities relative to stocks for most countries. Moreover, evidence indicates that real estate securities of some countries (but not others) do add incremental diversification benefits, even if stocks of that country are already included in an international portfolio.

The remainder of the paper is organized as follows. Section two describes the data set while the analytical framework is contained in section three. The existence of predictable excess real estate returns is documented in section four together with the extent that international real estate markets are integrated. Section five is the conclusion

\section{The Data}

Monthly returns on property trusts, and/or property-related securities, as well as capital market indices are obtained for Australia, France, Japan, South Africa, the U.K. and the U.S. The Australian Stock Exchange provided a market capitalization weighted index of listed property trusts. The Interactive Data Corporation (IDC), which is also the source of the CRSP data, furnished returns on individual property trusts in France from which a property trust return series inclusive of dividends is constructed. ${ }^{4}$ For Japan, returns on property companies are taken from the Nikkei Telecom News Retrieval system which reports Japanese value-weighted stock price indices by industry for the first section of the Tokyo Stock Exchange. B.O.E. Properties (Transvaal) Limited provided the value-weighted South Africa property unit trust index inclusive of dividends for the Johannesburg Stock Exchange. The Financial Times value weighted property index, which consists of property-related companies including a few developers, is used for the U.K. For U.S. real estate, the value weighted monthly index of equity real estate investment

\footnotetext{
${ }^{4}$ The total number of shares outstanding was unavailable for each property trust and a value weighted index was not constructed. The return data are adjusted for stock splits in an identical manner to that in the CRSP database. The stocks included in our index include Cofimeg, Cogifi, Foncina, GFIl, Sefimeg, Simco and Socim which are Slls, in addition to Codetel, Immoffice, Locindus and Unibail which are all Sicomis.
} 
trusts (EREITs) inclusive of dividends from the National Association of Real Estate Investment Trusts (NAREIT), is used. ${ }^{5}$

Information on stock market returns, short-term government yields, long-term government yields, consumer price indices and exchange rates are obtained from Ibbotson and Associates IDEAS database for each of the six countries. ${ }^{6}$ The Morgan Stanley Capital International Indices cum dividend is used as the proxy for capital market returns. ${ }^{7}$ All monthly return data for each country start in February 1980 and end in March 1991.

All of the return series are converted into U.S. returns to facilitate cross-country comparisons. As such, the perspective of the U.S. investor is assumed in this study. The formula used to translate returns on foreign assets into dollar terms is as follows:

(1) $\tilde{R}_{i \$}=\left(1+\tilde{R}_{i}\right)\left(1+\tilde{R}_{e i}\right)-1$

where the tilde " " represents a random variable, $\tilde{R}_{i \$}$ is the dollar rate of return on an unhedged investment in the $i^{\text {th }}$ foreign market, $\tilde{R}_{i}$ is the rate of return stated in local currency and $\tilde{R}_{e i}$ is the rate of appreciation of the local currency relative to the dollar. The framework of Eun and Resnick (1988) is used to compute returns using a hedged strategy using a foreign exchange forward contract, and alternatively, an unhedged strategy with respect to currency risk. This, in turn, permits determination of the benefits from international diversification. ${ }^{8}$ If currency risk is not hedged, then the expected rate of return, the actual rate of return, the variance of that return and the covariance of returns in terms of

\footnotetext{
${ }^{5}$ An adjustment was made to the NAREIT index since the dividend yield in the NAREIT index is calculated using current price $(f)$ rather than the price at the beginning of the period $(t-1)$. The index consists of all tax-qualified REITs listed on the New York Stock Exchange, the American Stock Exchange and the NASDAQ. Prior to 1987, REITs were included in the index for the January following their listing. After 1987, REITs were added to the index in the month that their shares were issued. The beginning of the month is used in calculating the value-weighted total return with only REITs listed for the entire period included in the index for that month.

${ }^{6}$ Ibbotson and Associates repackage data from several sources. For government yields and consumer price indices, the data is either from the International Monetary Fund's publication International Financial Statistics or the publications of the Organization of Economic Cooperation and Development (OECD) including Main EconomicIndicators and Financial Statistics: Part I. Exchange rates until 1987 are from OECD, Main Economic Indicators: Historical Statistics and after this date, The Wall Street Journal is used. Short-term government yields are derived from government instruments with less than three months to maturity or from an official discount rate. Long-term government yields, in contrast, assume that a single bond with a maturity of between 7.5 to 20 years is bought at par at the beginning of each period and then sold at the end of the period (e.g., a month at the then-prevailing market yield). The inflation rate is calculated as the change in the consumer price index from the beginning to the end of the month for each country. For Australia, however, the Producer Price Index taken from the I.M.F. International Financial Statistics is used as the proxy for inflation since the CPI is unavailable.

${ }^{7}$ The Financial Times stock index for South Africa was used as no Morgan Stanley Capital International Index exists.

${ }^{8}$ Eun and Resnick (1988) show that exchange rate fluctuations add to foreign investment risk by way of its own variance and also through its "positive" correlations with returns in the local stock market. In fact, a sizable portion of dollar stock volatility arises from exchange rate risk in developed countries. Hauser, Marcus and Yaari (1994) however, find that this phenomenon does not necessarily hold for stocks in emerging markets.
} 
dollars are as follows:

(2) Expected Return: $E\left(\widetilde{R}_{i \$}\right)=\left(1+E\left(\tilde{R}_{i}\right)\right)\left(1+E\left(\widetilde{R}_{e i}\right)\right)-1$

(3) Actual Return: ${ }^{9} \tilde{R}_{i \$}=\left(1+\tilde{R}_{i}\right)\left(1-\widetilde{R}_{e i}\right)-1 \approx \tilde{R}_{i}+\widetilde{R}_{e i}$

(4) Variance of Return: $\operatorname{var}\left(\tilde{R}_{i \$}\right) \approx \operatorname{var}\left(\tilde{R}_{i}\right)+\operatorname{var}\left(\tilde{R}_{e i}\right)+2 \operatorname{cov}\left(\tilde{R}_{i}, \tilde{R}_{e i}\right)$

(5) Covariance: $\operatorname{cov}\left(\tilde{R}_{i \$}, \tilde{R}_{j i}\right) \approx \operatorname{cov}\left(\tilde{R}_{i}, \tilde{R}_{j}\right)+\operatorname{cov}\left(\tilde{R}_{e i}, \tilde{R}_{e j}\right)+\operatorname{cov}\left(\tilde{R}_{i}, \tilde{R}_{e i}\right)+\operatorname{cov}\left(\tilde{R}_{j}, \tilde{R}_{e i}\right)$

where $" \approx$ " denotes an approximation and $E$ is the expectations operator. If a U.S. investor decides to hedge currency risk through a forward contract, Eun and Resnick (1988) show that the expected rate of return, the actual rate of return, the variance of that return and the covariance of returns in terms of dollars are as follows:

(6) Expected Return: $E\left(\tilde{R}_{i \$}^{H}\right)=\left(1+E\left(\tilde{R}_{i}\right)\right)\left(1+f_{i}\right)-1$

(7) Actual Return: $\tilde{R}_{i \$}^{H}=\left(1+E\left(\tilde{R}_{i}\right)\right)\left(1+f_{i}\right)+\left(\tilde{R}_{i}-E\left(\tilde{R}_{i}\right)\right)\left(1+\tilde{R}_{e i}\right)-1 \approx \tilde{R}_{i}+f_{i}$

(8) Variance of Returns: $\operatorname{var}\left(\tilde{R}_{i \$}^{H}\right) \approx \operatorname{var}\left(\tilde{R}_{i}\right)$

(9) Covariance: $\operatorname{cov}\left(\tilde{R}_{i \$}^{H}, \tilde{R}_{j \$}^{H}\right) \approx \operatorname{cov}\left(\tilde{R}_{i}, \tilde{R}_{j}\right)$

where superscript $H$ denotes the rate of return under the hedged strategy, /, is the relative forward exchange premium or discount and subscript $j$ refers to an asset $j$ which is different from asset $i$. To calculate the relative foreign exchange premium/discount the interest rate parity is assumed to hold ${ }^{10}$ so that

(10) $\frac{1+r_{\$}}{1+r_{i}}=1+f_{i}$

where $r_{\$}$ represents the U.S. risk-free rate and $r_{i}$ is the risk-free interest rate in the $i^{\text {th }}$ foreign country.

A comparison of Equations (4) and (8) reveals that if the covariance between return on the asset and return arising from currency fluctuations is positive, e.g., $\operatorname{cov}\left(\tilde{R}_{i}, \tilde{R}_{e i}\right)>0$, then the variance of the unhedged returns exceeds that of the hedged returns. Consequently, hedging currency risk is a superior strategy in this situation. ${ }^{11}$ If $\operatorname{cov}\left(\tilde{R}_{i}, \tilde{R}_{e i}\right)<0$ however, the hedged currency strategy is not necessarily superior to that of an unhedged strategy. Moreover, strategy to hedge currency risk is dependent on the extent to which currency risk contributes to the overall volatility. To further explore the contribution of currency risk to overall volatility of returns stated in dollar terms, the variance of returns in Equation (4)

\footnotetext{
${ }^{9}$ The actual return on an international investment in dollar terms actually consists of three components: the return on the asset $\left(R_{i}\right)$, the return on the currency $\left(R_{e i}\right)$, and the interaction between the return on the investment and the return on the currency $\left(R_{i} R_{e i}\right)$. Since the interaction term is small, it is omitted in all subsequent calculations. ${ }^{10}$ Frenkel and Levich (1977) among other others provide evidence supporting this assumption.

${ }^{11}$ This presumes that no settlement or transactions costs exist.
} 
are decomposed into two components: (1) the portion of the variance associated with own country variance $\left(V_{1}\right)$; and (2) the portion of the variance due to exchange rate risk $\left(V_{2}\right)$ as follows:

$$
1=V_{1}+V_{2}=\left[\frac{\operatorname{var}\left(\tilde{R}_{i}\right)}{\operatorname{var}\left(\tilde{R}_{i \$}\right)}\right]+\left[\frac{\operatorname{var}\left(\tilde{R}_{e i}\right)+2 \operatorname{cov}\left(\tilde{R}_{i}, \tilde{R}_{e i}\right)}{\operatorname{var}\left(\tilde{R}_{i \$}\right)}\right]
$$

\section{Characteristics of Foreign Property Trusts}

This study uses property trusts (except for Japan and the U.K. where property companies are employed) to increase the comparability of investing in real estate securities similar to that of U.S. property trusts. Foreign property trusts share many features with U.S. REITs. For one, shares of a property trust are traded on a stock exchange. Another similarity to REITs is that foreign property trusts are taxed only at the investor level. To qualify for tax exemption at the firm level, property trusts are required to distribute a certain percentage of net earnings, are subject to certain asset restrictions and are typically prohibited from engaging in certain real estate related activities. Most property trusts tend to have portfolios consisting of offices, retail and/or industrial properties. Some differences do exist, however, in that some foreign property trusts are limited in the amount of leverage they can use to purchase property. The leverage is typically much lower than that for U.S. REITs. In addition, while the U.S. has at least seven times more property trusts relative to other countries, the aggregate market capitalization of foreign property trusts (in U.S. dollars) is less than two times that of U.S. REITs. Table 1 provides detailed information on property trusts in various countries.

While this study searched for property trusts in all countries for which data was available, property companies had to be used for Japan and the U.K. There were no property trusts available for Japan. Although property unit trusts do exist in the U.K., their characteristics are more similar to that of U.S. commingled real estate funds (CREFs) than REITs. Admittedly, the use of property companies does create a comparability problem. In particular, property companies, in contrast to property trusts, take a more active role in real estate development since there are no prohibitions on certain real estate activities like those that exist for property trusts. As such, property companies tend to exhibit greater price volatility relative to property trusts in general. Also, property companies pa> taxes at the firm level. However, they do not have any distribution requirements as is the case with property trusts. While this may be a potential problem, it is not unrealistic to assume that if an investor wishes to participate in real estate-related securities, that investor will invest in property companies to get some exposure in a particular market if no property trusts are available. This study includes as many countries 
as possible in examining whether there are any incremental diversification advantages to investing in publicly traded real estate-related interests (preferably property trusts) over that of foreign stocks.

Table 1 a Characteristics of international property trusts.

\begin{tabular}{|c|c|c|c|c|}
\hline & Australia & France & South Africa & U.S. \\
\hline Number (1990) & 14 & 11 & 16 & 119 \\
\hline $\begin{array}{l}\text { Market Capitalization } \\
\text { Local Currency (1990) } \\
\text { U.S. Currency (1990) }\end{array}$ & $\begin{array}{l}\text { A } \$ 6.904 \text { billion } \\
\$ 5.352 \text { billion }\end{array}$ & $\begin{array}{l}\text { Francs } 26 \text { billion }^{a} \\
\$ 5.108 \text { billion }\end{array}$ & $\begin{array}{l}\mathrm{R} 3.400 \text { billion } \\
\$ .999 \text { billion }\end{array}$ & $\begin{array}{l}\$ 8.737 \text { billion } \\
\$ 8.737 \text { billion }\end{array}$ \\
\hline $\begin{array}{l}\text { Minimum Percentage of } \\
\text { Assets in Direct Property }\end{array}$ & $20^{b}$ & n.a. & n.a. & 75 \\
\hline Taxation at Firm Level & No & No & No & No \\
\hline Distribution Requirement & n.a. & $85 \%$ of net earnings & n.a. & $95 \%$ of Taxable Income \\
\hline Borrowing Restrictions & $20 \%$ of gross assets ${ }^{c}$ & n.a. & No borrowing & $\begin{array}{l}\text { Depends on REIT } \\
\text { declaration/charter }\end{array}$ \\
\hline Other Characteristics & $\begin{array}{l}\text { Largest group of net } \\
\text { funds invested in } \\
\text { property 1985-1989 } \\
(29 \%) \text {. Larger trusts own } \\
\text { CBD offices \& retail. } \\
\text { Smaller trusts own } \\
\text { suburban offices, retail } \\
\text { and industrial. }\end{array}$ & $\begin{array}{l}\text { Sicomis represented } 65 \% \\
\text { of commercial real estate } \\
\text { financings in } 1990 \text {. } \\
\text { Sicomis lease commercial } \\
\& \text { industrial properties } \\
\text { and are prohibited from } \\
\text { residential rental } \\
\text { activities. SIIs invest in } \\
\text { residential properties. }\end{array}$ & $\begin{array}{l}\text { Pension funds invest up } \\
\text { to } 30 \% \text { in property trusts. } \\
\text { Portfolios contain } \\
\text { industrial, office and/or } \\
\text { retail properties. }\end{array}$ & $\begin{array}{l}\text { Not more than } 30 \% \text { of } \\
\text { gross income can be } \\
\text { from sale of properties } \\
\text { held for less than four } \\
\text { years. }\end{array}$ \\
\hline
\end{tabular}

${ }^{4}$ Approximate market cap at year end 1991. The market cap is approximated using Ducrozant (1992).

${ }^{b}$ Most trusts invest $80 \%-85 \%$.

'Trusts, on average, use $7.5 \%$ of assets.

\section{The Analytical Framework}

To investigate whether international stock markets and markets for real estate related securities are integrated, both ordinary least square (OLS) regressions as well as the asset pricing framework described in Liu and Mei (1992) are used. First, OLS regressions of asset returns are performed for each country against own country state variables. ${ }^{12}$ The state variables used are a dummy variable for the January effect, the lagged short-term rate, the lagged spread in that country and lagged market returns. Lagged market returns are used to proxy for the dividend yield of an equally weighted portfolio because the latter is not available for many countries. This set of regressions gives an indication of the level of predictability of returns based on the own country information set. Next, excess asset returns are regressed (OLS) against common state variables where "common" is defined in terms of U.S. variables. The rationale for using U.S. variables is that international markets are studied from a U.S. investor's perspective. ${ }^{13}$ The common, economic state variables used are a January dummy, the T-bill, the spread

\footnotetext{
${ }^{12}$ This study is conducted from a U.S. investor's perspective. For a U.S. investor, only the currency adjusted return (unhedged) or the hedged return is available. Thus, this study focuses on currency adjusted returns (unhedged) and the hedged returns.

${ }^{13}$ There are two other reasons for using only the U.S. variables. First, the latent variable model could treat "omitted variables" as random errors. As such, the model is still well-specified even if variables of some other
} 
between the long-term and short-term rate and the dividend yield of an equally weighted portfolio. These regressions offer a partial test of international market integration. If a common set of U.S. variables can explain or predict the time-varying risk premiums for all assets across countries, then there is a strong indication of international market integration.

The forecasting variables chosen reflect those widely used in previous stock return and real estate securities studies (see Keim and Stambaugh 1986; Campbell 1987; Fama and French 1989; Ferson and Harvey 1991; Liu and Mei 1992; and Mei and Saunders 1995, among others). These studies have consistently shown that these variables are capable of explaining the time variation of expected returns over different sample periods and their use also conforms to asset pricing theories. These variables are also expected to act as important variables in this study. The January dummy captures the persistence in the positive rate of return during January. This effect has been found to be present for U.S. stocks during the 1970s. ${ }^{14}$ The January dummy is included to see if this seasonal effect is present in other security markets as well. The treasury bill rate proxies for the level of interest rates. A high relative bill rate is consistent with a sudden increase in the short-term interest rates in the economy and increased inflationary expectations, which could adversely impact the pay-off on real estate assets-especially those assets with relatively fixed nominal rental incomes-see Miles, Webb and Guilkey (1991). Thus, in periods when interest rates are higher (or lower) than "normal" a change might be expected in the interest-rate risk premium to be impounded in real estate security returns. The spread between the yield on long-term government bonds and the treasury bill rate proxies for the slope of the yield curve. A widening of the spread reflects investors' expectations of increased long-term inflation risk and thus may impact the present value of real estate assets, which are sensitive to long-term inflation. The dividend yield on equally-weighted stock portfolios seeks to capture changing expectations regarding expected future returns in the security markets. An increase in the risk (or perception) of security investment will increase the required rate of return on stocks and thus lower the market value of stocks. This, in turn, will result in an increase in the dividend yield. On the other hand, an unexpected increase in the future cash flows (dividends) to stocks will result in a higher dividend yield. A higher dividend yield makes stocks look more attractive to investors in terms of higher expected future returns.

country(ies) are left out. Thus, the test still holds with only U.S. variables. Second, was the need to be careful with degree of freedom restrictions. If variables are included from all countries, there will be spuriously high Rh but meaningless results

${ }^{14}$ Recent studies however have noted that the January effect was nonexistent in the late 1980s (e.g., Malkiel 1990). 
One question which arises is the extent to which the forecasting variables, denominated in own country currency, are correlated. Table 2 reveals that the state variables for a country exhibit only a modest correlation with the same state variables for another country in general. In fact, only eight of the correlation coefficients equal or exceed 0.5 between state variables of different countries. All of these eight correlations are statistically significant. Consequently, the majority of the correlations are low even though most are statistically significant due to the number of time periods used. While low correlations might suggest that segmentation exists since these variables might be expected to fluctuate together in an integrated market, Adler and Dumas (1983) point out that this rationale is misguided given that national random factors, such as politics, are reflected in these state variables. Thus, small correlations among national stock market indices, for example, are generally consistent with perfect capital market integration.

Table 2 a Correlation of economic state variables

\begin{tabular}{|c|c|c|c|c|c|c|c|c|c|c|c|c|c|c|c|c|c|c|c|}
\hline & $\begin{array}{l}\text { AUS } \\
\text { ST }\end{array}$ & $\begin{array}{l}\text { AUS } \\
\text { SP }\end{array}$ & $\begin{array}{l}\text { AUS } \\
\mathrm{M}\end{array}$ & $\begin{array}{l}\text { FR } \\
\text { ST }\end{array}$ & $\begin{array}{l}\text { FR } \\
\text { SP }\end{array}$ & $\begin{array}{l}\text { FR } \\
\text { M }\end{array}$ & $\begin{array}{l}\text { JP } \\
\text { ST }\end{array}$ & $\begin{array}{l}\text { JP } \\
\text { SP }\end{array}$ & $\begin{array}{l}\mathrm{JP} \\
\mathrm{M}\end{array}$ & $\begin{array}{l}\text { SAF } \\
\text { ST }\end{array}$ & $\begin{array}{l}\text { SAF } \\
\text { SP }\end{array}$ & $\begin{array}{l}\text { SAF } \\
\text { M }\end{array}$ & $\begin{array}{l}\text { UK } \\
\text { ST }\end{array}$ & $\begin{array}{l}\text { UK } \\
\text { SP }\end{array}$ & $\begin{array}{l}\text { UK } \\
\text { M }\end{array}$ & $\begin{array}{l}\text { US } \\
\text { ST }\end{array}$ & $\begin{array}{l}\text { US } \\
\text { SP }\end{array}$ & $\begin{array}{l}\text { US } \\
\mathrm{M}\end{array}$ & $\begin{array}{l}\text { US } \\
\text { DY }\end{array}$ \\
\hline AUS ST & 1 & & & & & & & & & & & & & & & & & & \\
\hline AUS SP & $-.6^{*}$ & 1 & & & & & & & & & & & & & & & & & \\
\hline AUS M & -.1 & .0 & 1 & & & & & & & & & & & & & & & & \\
\hline FR ST & .2 & .0 & -.2 & 1 & & & & & & & & & & & & & & & \\
\hline FR SP & -.2 & .4 & .1 & -.3 & 1 & & & & & & & & & & & & & & \\
\hline FR M & .3 & -.1 & .0 & .0 & -.1 & 1 & & & & & & & & & & & & & \\
\hline JP ST & .1 & .0 & -.1 & $.6^{*}$ & .1 & .1 & 1 & & & & & & & & & & & & \\
\hline JP SP & -.2 & .3 & -.1 & .0 & .0 & -.2 & $-.5 *$ & 1 & & & & & & & & & & & \\
\hline JP M & .1 & .0 & .3 & -.1 & .0 & .1 & .0 & -.1 & 1 & & & & & & & & & & \\
\hline SAF ST & .2 & -.2 & -.1 & .2 & -.2 & .1 & .1 & .0 & .0 & 1 & & & & & & & & & \\
\hline SAF SP & .2 & -.2 & .1 & -.2 & .3 & .0 & .1 & -.3 & .1 & -.4 & 1 & & & & & & & & \\
\hline SAF M & .1 & -.2 & .3 & .0 & -.1 & .1 & .1 & -.2 & .2 & $.5 *$ & .1 & 1 & & & & & & & \\
\hline UK ST & .3 & -.3 & -.1 & $.5^{*}$ & -.2 & .1 & $.5^{*}$ & -.4 & -.1 & .2 & .1 & .1 & 1 & & & & & & \\
\hline UK SP & -.3 & $.7 *$ & .0 & .1 & .4 & -.1 & .0 & $.5 *$ & .0 & -.2 & .0 & -.2 & $-.5 *$ & 1 & & & & & \\
\hline UK M & -.1 & -.1 & $.5 *$ & -.2 & .0 & .0 & .0 & -.1 & .4 & .1 & .0 & .3 & -.1 & -.1 & 1 & & & & \\
\hline US ST & -.1 & .2 & -.2 & .3 & -.2 & -.1 & .2 & .1 & -.2 & -.1 & -.2 & -.2 & .0 & .3 & -.1 & 1 & & & \\
\hline US SP & -.4 & $.5 *$ & -.1 & .3 & .1 & -.1 & .1 & .3 & -.1 & .0 & -.4 & -.2 & -.2 & $.6^{*}$ & -.1 & $.7 *$ & 1 & & \\
\hline US M & .1 & -.1 & .1 & -.1 & .0 & $.5 *$ & .0 & -.2 & -.1 & -.1 & .0 & .2 & .0 & -.1 & .0 & -.1 & -.2 & 1 & \\
\hline US DY & -.1 & .2 & -.1 & .3 & -.1 & -.1 & .3 & -.2 & -.2 & -.1 & -.2 & -.1 & .1 & .2 & .0 & $.7^{*}$ & $.7 *$ & .1 & 1 \\
\hline
\end{tabular}

All variables are in own country currency. AUS $=$ Australia, FR $=$ France, $J P=$ Japan, SAF $=$ South Africa, UK $=$ United Kingdom, $\mathrm{US}=$ United States, $\mathrm{ST}=$ short term rate, $\mathrm{SP}=$ spread of the long term rate over the short term rate, $\mathrm{M}=$ lag of market returm and DY $=$ equally weighted dividend yield. All correlation coefficients with an asterisk $(*)$ are statistically significant at the $5 \%$ level. The statistic used in calculating whether a correlation is significant is $S=\frac{c}{\sqrt{|c|(1-|c|)}} * \sqrt{T}$ where $c$ is the correlation coefficient, $|c|$ is the absolute value of the correlation coefficient and $T$ is the number of time periods. A correlation is significant, given the number of time periods, if $|S| \geq 2$.

In addition to OLS regressions, Hansen's Generalized Method of Moments (GMM) is also used in conjunction with the asset pricing framework set forth in Liu and Mei (1992) as a more rigorous test of international market integration. The asset pricing test not only imposes the restriction that the expected returns of all assets must be explained by a common set of state variables, but their movement must also satisfy some linear pricing restrictions outlined in the Appendix. It also has the advantage of being robust to heteroskedasticity in excess returns. More specifically, asset expected 
returns are fit using a latent variable model. If the international markets are integrated, then as Campbell and Hamao (1992) point out, the time-variation of risk premiums across different countries should satisfy the linear pricing restrictions determined by some systematic factors. A chi-squared test is used to examine the linear pricing restrictions imposed by the latent variable model. Initially the sample is divided into two markets, real estate related securities and stocks, due to the limited number of time series observations. Next, a chi-square test is conducted on each of the two separate samples to determine if the securitized property market is integrated, and alternatively, the stock market is integrated. If each respective market is integrated, an equally weighted international market index is constructed for real estate and stock, respectively, to see whether the international real estate market is integrated with the international stock market. The rationale for "collapsing" the seven countries into an international category is to circumvent the ranking (dimensionality) problem which arises from the limited number of time periods. The Appendix contains a more detailed discussion of the latent variable model and the associated test of linear pricing restrictions.

After examining whether international real estate markets are integrated, the issue of what is the optimal holdings of international assets from the perspective of a U.S. investor is explored. To do this, the mean-variance efficient portfolios is calculated for real estate, stocks and the combination real estate and stocks, respectively, assuming that no short sales are allowed. ${ }^{15}$

\section{Empirical Results}

Table 3 shows the average dollar return and the accompanying standard deviation for stocks and real estate-related securities in each country. Return and risk are reported on an unhedged and hedged currency basis together with the decomposition of volatility on unhedged returns. In terms of returns, Japanese stocks and property companies have the highest average monthly returns over the sample period regardless of whether currency risk is hedged. South African stocks and property trusts, in contrast, exhibit the lowest relative returns from both a hedged and unhedged perspective. South African stocks and property trusts also display the highest relative volatility in terms of unhedged returns. When currency risk is hedged, however, Australian stocks and Japanese property companies

\footnotetext{
${ }^{15}$ Mathematically, $\min x^{\prime} \mathbf{\Sigma} x$ s.t. $x^{\prime} \iota=1$ $x^{\prime} \mu=R_{p}$ $x \geq 0$
}

where $\mathrm{x}$ is the vector of weights, $\Sigma$ is the variance-covariance matrix of returns, $\mathrm{l}$ is the unity vector and $\mu$, is the vector of mean returns. 
have the highest inter-country risk. Not surprisingly, U.S. stocks and properly trusts have the lowest standard deviation. ${ }^{16}$ Interestingly, no linear risk-return tradeoff appears to exist regardless of whether currency risk is hedged. More specifically, both stocks and real estate related securities with relatively higher average returns do not necessarily have correspondingly higher standard deviations.

When the volatility of unhedged returns is partitioned, the exchange rate risk of the countries accounts for a sizable portion of the dollar return volatility for both stocks and real estate related securities. This evidence is consistent with prior studies on international stock diversification in developed markets. Consequently, hedging currency risk may be a desirable investment strategy. ${ }^{17}$ The impact of currency risk on stocks and property related securities differs depending on the country in question. For South Africa, exchange rate risk accounts for most of the variation in both returns on stocks and property trusts with the impact relatively larger for stocks. This situation also holds for Japan. In all other countries, however, currency risk accounts for a larger portion of the fluctuations in returns on property trusts/companies compared to stock returns in that country.

Table 4 presents the inter-country correlations and accompanying t-Statistics from an unhedged return perspective. Table 5 presents the same information when currency fluctuations are hedged. The correlations in both tables are relatively low across countries between different asset types indicating that gains are possible from international diversification in general. More specifically, the degree of comovement in the international property trust markets is low with an average inter-country correlation coefficient of $26(.19)$ if returns are unhedged (if currency risk is hedged). Similarly, the average intercountry correlation coefficient between international stocks is .34 and .36 for unhedged and hedged returns, respectively. While both sets of intra-asset correlations are low, returns tend to move more closely in international stock markets relative to the international property trust markets. This suggests larger diversification benefits are possible for a property trust portfolio relative to a stock portfolio if portfolio diversification is on an intra-asset basis. The degree of co-movement between stocks in one country, and real estate-related securities in a different country, is also low in general. In particular, the average inter-country correlation is .29 for unhedged returns and .26 for hedged returns. However, the intra-country correlations between stocks and property trusts/companies in both tables are moderate

\footnotetext{
${ }^{16}$ These returns are not adjusted for currency fluctuations.

${ }^{17}$ The degree to which hedging currency risk is desirable depends in part on the magnitude of settlement and other transaction costs which is not recognized here. See Worzala (1995) for details on how transaction costs can increase the variability of the portfolio.
} 
to high ranging from .62 to .80 if returns are unhedged and from .47 to .73 if currency risk is hedged. ${ }^{18}$ This suggests that while some incremental benefits do exist from adding international real estate securities to a portfolio of international stocks, the gain might be modest.

Table 3 - Decomposition of the volatility of the monthly rate of return: February 1980-March 1991.

\begin{tabular}{|c|c|c|c|c|c|c|}
\hline \multirow[b]{2}{*}{ Country } & \multicolumn{2}{|c|}{$\begin{array}{l}\text { Unhedged } \\
\text { Returns }\end{array}$} & \multicolumn{2}{|c|}{$\begin{array}{l}\text { Fraction }(\%) \text { of } \\
\text { Volatility }\end{array}$} & \multicolumn{2}{|c|}{$\begin{array}{l}\text { Hedged } \\
\text { Returns }\end{array}$} \\
\hline & $E\left(R_{i s}\right)$ & $\sigma\left(R_{i s}\right)$ & $V_{1}$ & $V_{2}$ & $E\left(\tilde{R}_{i, ~}^{H}\right)$ & $\sigma\left(\tilde{R}_{i \$}^{H}\right)$ \\
\hline \multicolumn{7}{|c|}{ Panel A: Stocks } \\
\hline Australia & 0.01 & 0.08 & 67.1 & 32.9 & 0.01 & 0.07 \\
\hline France & 0.02 & 0.07 & 76.5 & 23.5 & 0.02 & 0.06 \\
\hline Japan & 0.02 & 0.07 & 54.7 & 45.3 & 0.02 & 0.05 \\
\hline South Africa & -0.001 & 0.09 & 38.0 & 62.0 & 0.01 & 0.06 \\
\hline U.K. & 0.02 & 0.07 & 71.7 & 28.3 & 0.02 & 0.06 \\
\hline U.S. & 0.01 & 0.05 & 100.0 & 0.0 & 0.01 & 0.05 \\
\hline Average & 0.01 & 0.07 & 68.0 & 32.0 & 0.01 & 0.06 \\
\hline \multicolumn{7}{|c|}{ Panel B: Real Estate Related Securities } \\
\hline Australia & 0.01 & 0.05 & 54.4 & 45.6 & 0.01 & 0.04 \\
\hline France & 0.01 & 0.05 & 54.3 & 45.7 & 0.01 & 0.04 \\
\hline Japan & 0.02 & 0.08 & 60.1 & 39.9 & 0.02 & 0.06 \\
\hline South Africa & 0.01 & 0.09 & 45.5 & 54.5 & 0.01 & 0.06 \\
\hline U.K. & 0.01 & 0.07 & 68.5 & 31.5 & 0.01 & 0.06 \\
\hline U.S. & 0.01 & 0.03 & 100.0 & 0.0 & 0.01 & 0.03 \\
\hline Average & 0.01 & 0.06 & 63.8 & 36.2 & 0.01 & 0.05 \\
\hline
\end{tabular}

Note: $V_{1}=\operatorname{var}\left(\tilde{R}_{i}\right) / \operatorname{var}\left(\tilde{R}_{i \mathbf{s}}\right)=$ volatility due to own country risk and $V_{2}=\left(\operatorname{var}\left(\tilde{R}_{e i}\right)\right.$ $\left.+2 \operatorname{cov}\left(\tilde{R}_{i}, \tilde{R}_{e i}\right)\right) / \operatorname{var}\left(\tilde{R}_{i s}\right)=$ volatility due to currency risk.

Some differences also exist when the unhedged and hedged correlation structures are compared. For one, the intra-country correlations between stocks and property trusts/companies appear to be relatively lower when currency risk is hedged. This indicates that potentially larger gains from diversifying with international real estate securities exist if a U.S. investor hedges currency risk through a forward transaction. Secondly, the unhedged correlations do differ from the hedged correlations, although no clear pattern is evident as to the direction of the difference.

\footnotetext{
${ }^{18}$ Intra-country correlations between stocks and property trusts/companies are higher if returns are unhedged than if currency risk is hedged since both own-country returns are adjusted by the same currency factor each month in the former case. The authors thank an anonymous reviewer for this point.
} 
Table 4 - Unhedged correlations $\left[\operatorname{Corr}\left(\tilde{R}_{j \beta}, \tilde{R}_{j, \beta}\right)\right]$ (February 1980-March 1991).

\begin{tabular}{|c|c|c|c|c|c|c|c|c|c|c|c|c|}
\hline & $\begin{array}{l}\text { AUS } \\
\text { RE }\end{array}$ & $\begin{array}{l}\text { AUS } \\
\text { Stk }\end{array}$ & $\begin{array}{l}\text { FR } \\
\text { RE }\end{array}$ & $\begin{array}{l}\text { FR } \\
\text { Stk }\end{array}$ & $\begin{array}{l}\text { JP } \\
\text { RE }\end{array}$ & $\begin{array}{l}\text { JP } \\
\text { Stk }\end{array}$ & $\begin{array}{l}\text { SAF } \\
\text { RE }\end{array}$ & $\begin{array}{l}\text { SAF } \\
\text { Stk }\end{array}$ & $\begin{array}{l}\text { UK } \\
\text { RE }\end{array}$ & $\begin{array}{l}\text { UK } \\
\text { Stk }\end{array}$ & $\begin{array}{l}\text { US } \\
\text { RE }\end{array}$ & $\begin{array}{l}\text { US } \\
\text { Stk }\end{array}$ \\
\hline AUS RE & 1.00 & & & & & & & & & & & \\
\hline AUS Stk & $\begin{array}{r}0.80 \\
(14.8)^{a}\end{array}$ & 1.00 & & & & & & & & & & \\
\hline FR RE & $\begin{array}{c}0.51 \\
(6.6)^{\mathrm{a}}\end{array}$ & $\begin{array}{c}0.53 \\
(6.9)^{\mathrm{a}}\end{array}$ & 1.00 & & & & & & & & & \\
\hline FR Stk & $\begin{array}{c}0.54 \\
(7.1)^{\mathrm{a}}\end{array}$ & $\begin{array}{c}0.55 \\
(7.2)^{\mathrm{a}}\end{array}$ & $\begin{array}{r}0.64 \\
(9.2)^{3}\end{array}$ & 1.00 & & & & & & & & \\
\hline JP RE & $\begin{array}{c}0.20 \\
(2.3)^{2}\end{array}$ & $\begin{array}{c}0.22 \\
(2.5)^{\mathrm{a}}\end{array}$ & $\begin{array}{c}0.24 \\
(2.7)^{2}\end{array}$ & $\begin{array}{c}0.29 \\
(3.4)^{\mathrm{a}}\end{array}$ & 1.00 & & & & & & & \\
\hline JP Stk & $\begin{array}{c}0.24 \\
(2.8)^{\mathrm{a}}\end{array}$ & $\begin{array}{r}0.29 \\
(3.3)^{3}\end{array}$ & $\begin{array}{c}0.22 \\
(2.5)^{\mathrm{a}}\end{array}$ & $\begin{array}{c}0.31 \\
(3.6)^{a}\end{array}$ & $\begin{array}{r}0.70 \\
(11.0)^{2}\end{array}$ & 1.00 & & & & & & \\
\hline SAF RE & $\begin{array}{c}0.23 \\
(2.6)^{a}\end{array}$ & $\begin{array}{c}0.29 \\
(3.4)^{a}\end{array}$ & $\begin{array}{c}0.21 \\
(2.4)^{\mathrm{a}}\end{array}$ & $\begin{array}{c}0.21 \\
(2.3)^{2}\end{array}$ & $\begin{array}{c}0.14 \\
(1.7)^{b}\end{array}$ & $\begin{array}{c}0.26 \\
(3.0)^{\mathrm{a}}\end{array}$ & 1.00 & & & & & \\
\hline SAF Stk & $\begin{array}{c}0.16 \\
(1.8)^{a}\end{array}$ & $\begin{array}{c}0.20 \\
(2.2)^{x}\end{array}$ & $\begin{array}{r}0.04 \\
(0.4)\end{array}$ & $\begin{array}{c}0.14 \\
(1.6)^{b}\end{array}$ & $\begin{array}{c}0.21 \\
(2.4)^{\mathrm{a}}\end{array}$ & $\begin{array}{c}0.28 \\
(3.3)^{4}\end{array}$ & $\begin{array}{r}0.79 \\
(14.2)^{4}\end{array}$ & 1.00 & & & & \\
\hline UK RE & $\begin{array}{r}0.50 \\
(6.4)^{\mathrm{a}}\end{array}$ & $\begin{array}{c}0.51 \\
(6.6)=\end{array}$ & $\begin{array}{c}0.32 \\
(3.7)^{2}\end{array}$ & $\begin{array}{c}0.36 \\
(4.3)^{n}\end{array}$ & $\begin{array}{c}0.30 \\
(3.5)^{\circ}\end{array}$ & $\begin{array}{c}0.37 \\
(4.5)^{4}\end{array}$ & $\begin{array}{r}0.13 \\
(1.5)\end{array}$ & $\begin{array}{c}0.09 \\
(1.0)\end{array}$ & 1.00 & & & \\
\hline UK Stk & $\begin{array}{r}0.45 \\
(5.5)^{2}\end{array}$ & $\begin{array}{c}0.55 \\
(7.2)^{2}\end{array}$ & $\begin{array}{c}0.33 \\
(3.9)^{\mathrm{a}}\end{array}$ & $\begin{array}{c}0.47 \\
(5.9)^{2}\end{array}$ & $\begin{array}{c}0.32 \\
(3.7)^{\mathrm{a}}\end{array}$ & $\begin{array}{c}0.41 \\
(4.9)^{\mathrm{a}}\end{array}$ & $\begin{array}{c}0.23 \\
(2.6)^{\mathrm{x}}\end{array}$ & $\begin{array}{c}0.16 \\
(1.8)^{\mathrm{a}}\end{array}$ & $\begin{array}{r}0.82 \\
(15.7)^{\mathrm{a}}\end{array}$ & 1.00 & & \\
\hline US RE & $\begin{array}{r}0.30 \\
(3.5)^{3}\end{array}$ & $\begin{array}{c}0.38 \\
(4.6)^{2}\end{array}$ & $\begin{array}{r}0.13 \\
(1.4)\end{array}$ & $\begin{array}{c}0.35 \\
(4.1)^{2}\end{array}$ & $\begin{array}{r}0.11 \\
(1.2)\end{array}$ & $\begin{array}{c}0.24 \\
(2.8)^{a}\end{array}$ & $\begin{array}{c}0.15 \\
(1.7)^{\mathrm{a}}\end{array}$ & $\begin{array}{l}0.12 \\
(1.3)\end{array}$ & $\begin{array}{r}0.38 \\
(4.6)^{\mathrm{a}}\end{array}$ & $\begin{array}{c}0.52 \\
(6.8)^{4}\end{array}$ & 1.00 & \\
\hline US Stk & $\begin{array}{c}0.30 \\
(3.5)^{2}\end{array}$ & $\begin{array}{c}0.44 \\
(5.4)^{a}\end{array}$ & $\begin{array}{c}0.19 \\
(2.2)^{\mathrm{a}}\end{array}$ & $\begin{array}{c}0.47 \\
(6.0)^{\mathrm{s}}\end{array}$ & $\begin{array}{c}0.09 \\
(1.0)\end{array}$ & $\begin{array}{c}0.25 \\
(2.8)^{\mathrm{a}}\end{array}$ & $\begin{array}{c}0.15 \\
(1.7)^{\mathrm{a}}\end{array}$ & $\begin{array}{c}0.10 \\
(1.1)\end{array}$ & $\begin{array}{c}0.38 \\
(4.5)^{a}\end{array}$ & $\begin{array}{r}0.55 \\
(7.4)^{\mathrm{a}}\end{array}$ & $\begin{array}{c}0.62 \\
(8.8)^{\mathrm{a}}\end{array}$ & 1.00 \\
\hline \multicolumn{13}{|c|}{$\begin{array}{l}\text { AUS }=\text { Australia, FR }=\text { France, JP }=\text { Japan, } \mathrm{SAF}=\text { South Africa, UK }=\text { United Kingdom, US }=\text { United States, Stk }=\text { stock and RE }= \\
\text { real estate. Significance levels are calculated by treating }(N-2)^{1 / 2} \rho /\left(1-\rho^{2}\right)^{1 / 2} \text { as coming from a } t \text {-distribution with } N-2 \text { degrees of } \\
\text { freedom, where } N \text { is the appropriate sample size }(134 \text { in this study) and } \rho \text { is the Pearson correlation coefficient. } t \text {-Statistics are in parenthesis. } \\
\text { Subscripts } i \text { and } j \text { associated with } R \text { refer to the return }(R) \text { on asset } i \text { and asset } j \text {, respectively, where } i \neq j .\end{array}$} \\
\hline $\begin{array}{l}\text { aSignific } \\
{ }^{b} \text { Signific }\end{array}$ & $\begin{array}{l}\text { the } 5 \% \\
\text { the } 10 \%\end{array}$ & $\begin{array}{l}\text { I. } \\
\text { el. }\end{array}$ & & & & & & & & & & \\
\hline
\end{tabular}

Table 5 - Hedged correlations $\left[\operatorname{Corr}\left(\tilde{R}_{i 5}^{H}, \tilde{R}_{j s}^{H}\right)\right]$ (February 1980-March 1991).

\begin{tabular}{|c|c|c|c|c|c|c|c|c|c|c|c|c|}
\hline & $\begin{array}{l}\text { AUS } \\
\text { RE }\end{array}$ & $\begin{array}{l}\text { AUS } \\
\text { Stk }\end{array}$ & $\begin{array}{l}\text { FR } \\
\text { RE }\end{array}$ & $\begin{array}{l}\text { FR } \\
\text { Stk }\end{array}$ & $\begin{array}{l}\text { JP } \\
\text { RE }\end{array}$ & $\begin{array}{l}\text { JP } \\
\text { Stk }\end{array}$ & $\begin{array}{l}\text { SAF } \\
\text { RE }\end{array}$ & $\begin{array}{l}\text { SAF } \\
\text { Stk }\end{array}$ & $\begin{array}{l}\text { UK } \\
\text { RE }\end{array}$ & $\begin{array}{l}\text { UK } \\
\text { Stk }\end{array}$ & $\begin{array}{l}\text { US } \\
\text { RE }\end{array}$ & $\begin{array}{l}\text { US } \\
\text { Stk }\end{array}$ \\
\hline AUS RE & 1.00 & & & & & & & & & & & \\
\hline AUS Stk & $\begin{array}{c}0.65 \\
(9.5)^{a}\end{array}$ & 1.00 & & & & & & & & & & \\
\hline FR RE & $\begin{array}{c}0.09 \\
(1.0)\end{array}$ & $\begin{array}{c}0.19 \\
(2.2)^{\mathrm{a}}\end{array}$ & 1.00 & & & & & & & & & \\
\hline FR Stk & $\begin{array}{c}0.32 \\
(3.7)^{\mathrm{a}}\end{array}$ & $\begin{array}{c}0.35 \\
(4.1)^{\mathrm{a}}\end{array}$ & $\begin{array}{c}0.48 \\
(6.0)^{a}\end{array}$ & 1.00 & & & & & & & & \\
\hline JP RE & $\begin{array}{c}0.11 \\
(1.2)\end{array}$ & $\begin{array}{r}0.13 \\
(1.4)\end{array}$ & $\begin{array}{c}0.09 \\
(1.0)\end{array}$ & $\begin{array}{c}0.25 \\
(2.8)^{\mathrm{a}}\end{array}$ & 1.00 & & & & & & & \\
\hline JP Stk & $\begin{array}{c}0.27 \\
(3.1)^{\mathrm{a}}\end{array}$ & $\begin{array}{c}0.27 \\
(3.2)^{\mathrm{a}}\end{array}$ & $\begin{array}{r}0.11 \\
(1.2)\end{array}$ & $\begin{array}{r}0.32 \\
(3.7)^{\mathrm{a}}\end{array}$ & $\begin{array}{c}0.47 \\
(6.0)^{\mathrm{a}}\end{array}$ & 1.00 & & & & & & \\
\hline SAF RE & $\begin{array}{c}0.23 \\
(2.7)^{\mathrm{a}}\end{array}$ & $\begin{array}{c}0.34 \\
(4.0)^{a}\end{array}$ & $\begin{array}{c}0.16 \\
(1.8)^{a}\end{array}$ & $\begin{array}{c}0.16 \\
(1.8)^{a}\end{array}$ & $\begin{array}{r}0.01 \\
(0.2)\end{array}$ & $\begin{array}{c}0.16 \\
(1.8)^{a}\end{array}$ & 1.00 & & & & & \\
\hline SAF Stk & $\begin{array}{c}0.22 \\
(2.5)^{\mathrm{a}}\end{array}$ & $\begin{array}{c}0.26 \\
(3.0)^{a}\end{array}$ & $\begin{array}{l}-0.07 \\
(-0.8)\end{array}$ & $\begin{array}{c}0.15 \\
(1.7)^{\mathrm{a}}\end{array}$ & $\begin{array}{c}0.16 \\
(1.8)^{a}\end{array}$ & $\begin{array}{c}0.24 \\
(2.8)^{\mathrm{a}}\end{array}$ & $\begin{array}{c}0.49 \\
(6.2)^{\mathrm{a}}\end{array}$ & 1.00 & & & & \\
\hline UK RE & $\begin{array}{c}0.51 \\
(6.5)^{a}\end{array}$ & $\begin{array}{r}0.46 \\
(5.7)^{\mathrm{a}}\end{array}$ & $\begin{array}{r}0.07 \\
(0.8)\end{array}$ & $\begin{array}{c}0.27 \\
(3.1)^{\mathrm{a}}\end{array}$ & $\begin{array}{c}0.08 \\
(0.9)\end{array}$ & $\begin{array}{c}0.27 \\
(3.1)^{a}\end{array}$ & $\begin{array}{c}0.18 \\
(2.0)^{\mathrm{a}}\end{array}$ & $\begin{array}{c}0.14 \\
(1.6)^{6}\end{array}$ & 1.00 & & & \\
\hline UK Stk & $\begin{array}{c}0.46 \\
(5.8)^{\mathrm{a}}\end{array}$ & $\begin{array}{c}0.52 \\
(6.7)^{\circ}\end{array}$ & $\begin{array}{c}0.14 \\
(1.6)^{b}\end{array}$ & $\begin{array}{c}0.45 \\
(5.5)^{\prime \prime}\end{array}$ & $\begin{array}{c}0.14 \\
(1.6)^{b}\end{array}$ & $\begin{array}{r}0.39 \\
(4.7)^{\mathrm{a}}\end{array}$ & $\begin{array}{c}0.33 \\
(3.9)^{8}\end{array}$ & $\begin{array}{c}0.25 \\
(2.9)^{4}\end{array}$ & $\begin{array}{r}0.73 \\
(11.8)^{a}\end{array}$ & 1.00 & & \\
\hline US RE & $\begin{array}{c}0.38 \\
(4.5)^{\mathrm{a}}\end{array}$ & $\begin{array}{c}0.46 \\
(5.7)^{\mathrm{a}}\end{array}$ & $\begin{array}{c}0.15 \\
(1.6)^{b}\end{array}$ & $\begin{array}{c}0.38 \\
(4.5)^{a}\end{array}$ & $\begin{array}{c}0.17 \\
(1.9)^{\mathrm{a}}\end{array}$ & $\begin{array}{c}0.37 \\
(4.4)^{a}\end{array}$ & $\begin{array}{c}0.23 \\
(2.6)^{\mathrm{a}}\end{array}$ & $\begin{array}{c}0.20 \\
(2.3)^{\mathrm{a}}\end{array}$ & $\begin{array}{c}0.46 \\
(5.8)^{3}\end{array}$ & $\begin{array}{c}0.62 \\
(8.7)^{\text {a }}\end{array}$ & 1.00 & \\
\hline US Stk & $\begin{array}{c}0.33 \\
(3.8)^{a}\end{array}$ & $\begin{array}{r}0.49 \\
(6.3)^{a}\end{array}$ & $\begin{array}{c}0.18 \\
(2.1)^{\mathrm{a}}\end{array}$ & $\begin{array}{r}0.49 \\
(6.3)^{a}\end{array}$ & $\begin{array}{r}0.13 \\
(1.4)\end{array}$ & $\begin{array}{c}0.35 \\
(4.1)^{n}\end{array}$ & $\begin{array}{r}0.30 \\
(3.5)^{9}\end{array}$ & $\begin{array}{c}0.24 \\
(2.7)^{\alpha}\end{array}$ & $\begin{array}{c}0.47 \\
(5.9)^{a}\end{array}$ & $\begin{array}{c}0.67 \\
(10.1)^{a}\end{array}$ & $\begin{array}{c}0.62 \\
(8.8)^{\mathrm{a}}\end{array}$ & 1.00 \\
\hline
\end{tabular}

AUS $=$ Australia, FR $=$ France, $\mathrm{JP}=$ Japan, SAF $=$ South Africa, UK $=$ United Kingdom. US $=$ United States, Stk $=$ stock and RE $=$ real estate. Significance levels are calculated by treating $(N-2)^{1 / 2} \rho /\left(1-\rho^{2}\right)^{1 / 2}$ as coming from a $t$-distribution with $N-2$ degrees of freedom, where $N$ is the appropriate sample size (134 in this study) and $\rho$ is the Pearson correlation coefficient. $t$-Statistics are in parenthesis. Subscripts $i$ and $j$ associated with $R$ refer to the return $(R)$ on asset $i$ and asset $j$, respectively, where $i \neq j$.

significant at the $5 \%$ level.

'Significant at the $10 \%$ level. 
To determine the role that hedging exchange rate risk has on expected returns and in turn, the impact that fluctuations in expected returns have on the movement of actual returns, a series of regressions is performed. The results for the first set of OLS regressions, which explores the question of how predictable returns are for each country using own country state variables as the relevant information set, are reported in Table 6. These variables are in local currency since the intuition is to proxy tor each country's economic condition. The results for the second set of OLS regressions, reported in Table 7, examine the related question of how predictable returns are for each country. Table 7, in contrast to Table 6, uses a set of common U.S. state variables in lieu of own country economic variables. The U.S. variables are in U.S. currency since: (1) this provides evidence of whether U.S. variables are more important relative to own country economic variables in predicting returns; (2) this gives an indication of whether international markets are integrated; and (3) international markets are studied from a U.S. investor's perspective.

Table 6 illustrates that own country state variables account for a portion of the variation in the expected rates of return in some countries but not in others. Own country variables for Japan and South Africa play a significant role in predicting returns on real estate securities in both countries regardless of whether exchange rate risk is hedged. This is also the case, to a weaker extent, for unhedged U.S. property returns For expected returns on Japanese property companies, hedging exchange rate risk reduces the role of own country variables. The converse is true for expected returns on South African property trusts. Own country variables for South Africa are also important in accounting for the variation in South African stock returns regardless of whether exchange rate risk is hedged. For Japan, in contrast, own country variables are not influential with respect to stock returns on either an unhedged or hedged basis. Own country variables are also related to movements in unhedged U.K. stock returns although to a more limited extent relative to South Africa. While the preceding evidence indicates that own country economic variables as well as exchange rate risk do influence expected returns, this evidence is relatively weak as reflected in the relatively low F-Statistics and adjusted $R h$. In general, only minor differences exist between using an unhedged or hedged strategy with respect to capturing expected rates of return. Consistent with Liu and Mei (1992), short-term rates and the spreads are negatively related to expected asset returns in general. 
Table 6 - Regression of asset returns against own country state variables.

\begin{tabular}{|c|c|c|c|c|c|c|c|c|c|c|c|c|c|c|}
\hline & \multicolumn{7}{|l|}{ Property } & \multicolumn{7}{|l|}{ Stocks } \\
\hline & Constant & January & $\begin{array}{l}\text { ST } \\
\text { Rate }\end{array}$ & Spread & $M k_{t-1}$ & $F$-Stat & $\begin{array}{c}\text { Adj. } \\
R^{2}\end{array}$ & Constant & January & $\begin{array}{l}\text { ST } \\
\text { Rate }\end{array}$ & Spread & $M k_{r-1}$ & $F$-Stat & $\begin{array}{c}\text { Adj. } \\
R^{2}\end{array}$ \\
\hline \multicolumn{15}{|c|}{ Panel A: Unhedged } \\
\hline Australia & $\begin{array}{c}0.00 \\
(0.1)\end{array}$ & $\begin{array}{c}0.02 \\
(1.1)\end{array}$ & $\begin{array}{c}0.06 \\
(0.3)\end{array}$ & $\begin{array}{l}-0.03 \\
(-0.1)\end{array}$ & $\begin{array}{r}0.01 \\
(0.2)\end{array}$ & 0.4 & -0.02 & $\begin{array}{c}0.03 \\
(0.8)\end{array}$ & $\begin{array}{c}0.00 \\
(0.0)\end{array}$ & $\begin{array}{l}-0.13 \\
(-0.5)\end{array}$ & $\begin{array}{c}-0.38 \\
(-0.9)\end{array}$ & $\begin{array}{c}0.02 \\
(0.1)\end{array}$ & 0.2 & -0.03 \\
\hline France & $\begin{array}{c}0.03 \\
(2.1)^{\mathrm{a}}\end{array}$ & $\begin{array}{c}-0.02 \\
(-0.9)\end{array}$ & $\begin{array}{l}-0.01 \\
(-1.1)\end{array}$ & $\begin{array}{l}-0.45 \\
(-0.9)\end{array}$ & $\begin{array}{c}0.09 \\
(1.4)\end{array}$ & 1.1 & 0.00 & $\begin{array}{c}0.02 \\
(1.2)\end{array}$ & $\begin{array}{c}0.01 \\
(0.6)\end{array}$ & $\begin{array}{l}-0.05 \\
(-0.3)\end{array}$ & $\begin{array}{l}-0.52 \\
(-0.8)\end{array}$ & $\begin{array}{c}0.05 \\
(0.5)\end{array}$ & 0.3 & -0.02 \\
\hline Japan & $\begin{array}{c}0.03 \\
(2.2)^{\mathrm{a}}\end{array}$ & $\begin{array}{c}-0.06 \\
(-2.1)^{\mathrm{a}}\end{array}$ & $\begin{array}{l}-0.26 \\
(-1.3)\end{array}$ & $\begin{array}{c}-1.17 \\
(-1.6)^{b}\end{array}$ & $\begin{array}{r}0.54 \\
(4.2)^{2}\end{array}$ & $6.6^{\mathrm{a}}$ & 0.15 & $\begin{array}{c}0.02 \\
(1.5)\end{array}$ & $\begin{array}{l}-0.01 \\
(-0.2)\end{array}$ & $\begin{array}{l}-0.01 \\
(-0.1)\end{array}$ & $\begin{array}{l}-0.52 \\
(-0.8)\end{array}$ & $\begin{array}{r}0.11 \\
(0.9)\end{array}$ & 0.6 & -0.01 \\
\hline South Africa & $\begin{array}{c}0.06 \\
(2.3)^{\mathrm{a}}\end{array}$ & $\begin{array}{c}0.02 \\
(0.7)\end{array}$ & $\begin{array}{c}-0.37 \\
(-2.2)^{\mathrm{a}}\end{array}$ & $\begin{array}{c}-0.47 \\
(-1.8)^{\mathrm{b}}\end{array}$ & $\begin{array}{c}0.32 \\
(2.4)^{a}\end{array}$ & $1.8^{\mathrm{b}}$ & 0.03 & $\begin{array}{c}0.05 \\
(1.9)^{\mathrm{a}}\end{array}$ & $\begin{array}{c}0.05 \\
(1.7)^{\mathrm{b}}\end{array}$ & $\begin{array}{c}-0.39 \\
(-2.4)^{\mathrm{a}}(\end{array}$ & $\begin{array}{l}-0.30 \\
(-1.2)\end{array}$ & $\begin{array}{r}0.48 \\
(3.7)^{\mathrm{a}}\end{array}$ & $4.5^{\mathrm{a}}$ & 0.10 \\
\hline U.K. & $\begin{array}{r}0.01 \\
(0.4)\end{array}$ & $\begin{array}{c}0.00 \\
(0.0)\end{array}$ & $\begin{array}{c}0.05 \\
(0.3)\end{array}$ & $\begin{array}{l}-0.43 \\
(-1.0)\end{array}$ & $\begin{array}{l}-0.19 \\
(-1.6)\end{array}$ & 1.0 & 0.00 & $\begin{array}{r}-0.01 \\
(-0.3)\end{array}$ & $\begin{array}{c}0.02 \\
(1.0)\end{array}$ & $\begin{array}{c}0.19 \\
(1,2)\end{array}$ & $\begin{array}{l}-0.46 \\
(-1.3)\end{array}$ & $\begin{array}{r}-0.20 \\
(-1.9)^{\mathrm{a}}\end{array}$ & $2.0^{\mathrm{b}}$ & 0.03 \\
\hline U.S. & $\begin{array}{r}-0.01 \\
(-0.4)\end{array}$ & $\begin{array}{c}0.02 \\
(1.4)\end{array}$ & $\begin{array}{c}-3.75 \\
(-2.1)^{\mathrm{a}}\end{array}$ & $\begin{array}{c}0.42 \\
(1.8)^{b}\end{array}$ & $\begin{array}{r}0.10 \\
(1.5)\end{array}$ & $2.2^{\mathrm{b}}$ & 0.04 & $\begin{array}{r}0.03 \\
(1.0)\end{array}$ & $\begin{array}{r}0.01 \\
(0.8)\end{array}$ & $\begin{array}{r}-0.17 \\
(-0.7)\end{array}$ & $\begin{array}{l}-0.01 \\
(-0.0)\end{array}$ & $\begin{array}{r}0.01 \\
(0.1)\end{array}$ & 0.4 & -0.02 \\
\hline \multicolumn{15}{|c|}{ Panel B: Hedged } \\
\hline Australia & $\begin{array}{r}0.04 \\
(0.8)\end{array}$ & $\begin{array}{c}0.02 \\
(0.5)\end{array}$ & $\begin{array}{c}-0.09 \\
(-0.3)\end{array}$ & $\begin{array}{c}-0.34 \\
(-0.6)\end{array}$ & $\begin{array}{l}0.02 \\
(0.3)\end{array}$ & 0.2 & -0.03 & $\begin{array}{r}0.06 \\
(1.1)\end{array}$ & $\begin{array}{r}-0.00 \\
(-0.0)\end{array}$ & $\begin{array}{l}-0.28 \\
(-0.6)\end{array}$ & $\begin{array}{r}0.68 \\
(-0.9)\end{array}$ & $\begin{array}{c}0.03 \\
(0.3)\end{array}$ & 0.2 & -0.03 \\
\hline France & $\begin{array}{c}0.05 \\
(1.8)^{\mathrm{b}}\end{array}$ & $\begin{array}{l}-0.01 \\
(-0.2)\end{array}$ & $\begin{array}{l}-0.11 \\
(-0.5)\end{array}$ & $\begin{array}{l}-0.97 \\
(-1.1)\end{array}$ & $\begin{array}{r}0.09 \\
(1.3)\end{array}$ & 0.8 & -0.01 & $\begin{array}{r}0.04 \\
(1.1)\end{array}$ & $\begin{array}{c}0.02 \\
(0.6)\end{array}$ & $\begin{array}{c}-0.04 \\
(-0.1)\end{array}$ & $\begin{array}{l}-1.04 \\
(-0.8)\end{array}$ & $\begin{array}{r}0.07 \\
(0.7)\end{array}$ & 0.4 & -0.02 \\
\hline Japan & $\begin{array}{c}0.03 \\
(1.5)\end{array}$ & $\begin{array}{l}-0.04 \\
(-1.1)\end{array}$ & $\begin{array}{l}-0.02 \\
(-0.1)\end{array}$ & $\begin{array}{r}-1.04 \\
\{-1.0\}\end{array}$ & $\begin{array}{r}0.31 \\
(3.2)^{\mathrm{a}}\end{array}$ & $3.8^{\mu}$ & 0.08 & $\begin{array}{r}0.03 \\
(1.3)\end{array}$ & $\begin{array}{r}0.01 \\
(0.2)\end{array}$ & $\begin{array}{c}0.08 \\
(0.3)\end{array}$ & $\begin{array}{l}-0.58 \\
(-0.5)\end{array}$ & $\begin{array}{c}0.08 \\
(0.8)\end{array}$ & 0.5 & -0.02 \\
\hline South Africa & $\begin{array}{c}0.05 \\
(1.9)^{4}\end{array}$ & $\begin{array}{r}0.03 \\
(0.8)\end{array}$ & $\begin{array}{c}-0.31 \\
(-\mathrm{i} .7)^{5}\end{array}$ & $\begin{array}{r}-0.44 \\
(-1.3)\end{array}$ & $\begin{array}{r}0.32 \\
\left(3.3 r^{4}\right.\end{array}$ & $3.1^{4}$ & 0.06 & $\begin{array}{r}0.04 \\
(1.3)\end{array}$ & $\begin{array}{l}0.06 \\
(1.4)\end{array}$ & $\begin{array}{c}-0.28 \\
(-1.4)\end{array}$ & $\begin{array}{l}-0.22 \\
(-0.6)\end{array}$ & $\begin{array}{c}0.41 \\
(3.9)^{a}\end{array}$ & $4.9^{a}$ & 0.11 \\
\hline U.K. & $\begin{array}{c}0.02 \\
(0.6)\end{array}$ & $\begin{array}{r}0.04 \\
(0.9)\end{array}$ & $\begin{array}{r}0.12 \\
(0.5)\end{array}$ & $\begin{array}{r}-0.41 \\
(-0.6)\end{array}$ & $\begin{array}{r}-0.17 \\
(-1.8)^{\mathrm{b}}\end{array}$ & 1.1 & 0.00 & $\begin{array}{r}0.01 \\
(0.2)\end{array}$ & $\begin{array}{c}0.06 \\
(1.5)\end{array}$ & $\begin{array}{r}0.25 \\
(1.0)\end{array}$ & $\begin{array}{c}-0.44 \\
(-0.7)\end{array}$ & $\begin{array}{c}-0.17 \\
(1.8)^{b}\end{array}$ & 1.7 & 0.02 \\
\hline U.S. & $\begin{array}{c}0.02 \\
(0.5)\end{array}$ & $\begin{array}{r}0.03 \\
(1.2)\end{array}$ & $\begin{array}{r}-5.41 \\
(-1.4)\end{array}$ & $\begin{array}{r}0.41 \\
(0.8)\end{array}$ & $\begin{array}{r}0.06 \\
(0.8)\end{array}$ & 1.0 & 0.00 & $\begin{array}{r}0.05 \\
(1.0)\end{array}$ & $\begin{array}{c}0.03 \\
(0.8)\end{array}$ & $\begin{array}{c}-3.33 \\
(-0.7)\end{array}$ & $\begin{array}{l}-0.02 \\
(-0.0)\end{array}$ & $\begin{array}{r}0.01 \\
(0.1)\end{array}$ & 0.4 & -0.02 \\
\hline
\end{tabular}

Degrees of freedom for the $F$-Statistic are $\mathrm{F}(4.120)$. $t$-Statistics are in parenthesis.

aSignificant at 5\% level.

${ }^{\circ}$ Significant at $10 \%$ level.

Table 7 reveals a similar story to Table 6 . While some differences are present with respect to which U.S. common variables are useful in predicting returns due to currency hedging, this difference is not significant. Stated differently, only minor differences exist between using an unhedged or hedged strategy, in general, with respect to capturing expected rates of return when U.S. economic variables are substituted for own country state variables. However, some conflicting evidence exists as to which information set is more useful in predicting returns. A comparison of Tables 7 and 6 reveals that U.S. economic variables appear to be better predictors of individual country returns on both stocks and real estate securities. The F-Statistics are significant and the adjusted $R^{2} s$ are slightly higher when the set of U.S. economic variables is used relative to own country economic variables for more countries. However, own country economic variables have more explanatory power based on the adjusted $R^{2}$ for unhedged and hedged returns on Japanese property companies and also South African stocks. South African economic variables also account for more of the variation in hedged returns on South African property trusts relative to U.S. economic variables. In all other cases, however, U.S. economic variables are slightly better predictors of individual country returns on both stocks and real estate securities relative to own country variables. The adjusted $R^{2} s$ in Table 7 also suggest that U.S. real estate securities 
are more predictable relative to other U.S. stocks. This is consistent with the findings of Liu and Mei (1992). Returns on foreign stocks are relatively more predictable relative to the returns on foreign real estate securities in general. Another interesting observation is that the January effect is insignificant in all countries and for all assets except for South African stocks.

Table 7 a Regression of asset returns against common U.S. state variables.

\begin{tabular}{|c|c|c|c|c|c|c|c|c|c|c|c|c|c|c|}
\hline & \multicolumn{7}{|l|}{ Property } & \multicolumn{7}{|l|}{ Stocks } \\
\hline & Constant & January & T-bill & Spread & DivYld & Id $F$-Stat & $\begin{array}{l}\text { Adj. } \\
R^{2}\end{array}$ & Constant & January & T-bill & Spread & DivYl & Id $F$-Sta & $\begin{array}{l}\text { Adj. } \\
\text { tat } R^{2}\end{array}$ \\
\hline \multicolumn{15}{|c|}{ Panel A: Unhedged } \\
\hline Australia & $\begin{array}{c}0.05 \\
(1.9)^{\mathrm{b}}\end{array}$ & $\begin{array}{c}0.02 \\
(1.0)\end{array}$ & $\begin{array}{l}-0.00 \\
(-1.1)\end{array}$ & $\begin{array}{c}-0.00 \\
(-1.3)\end{array}$ & $\begin{array}{c}-0.01 \\
(-0.5)\end{array}$ & 1.2 & 0.01 & $\begin{array}{r}0.09 \\
(2.3)^{\mathrm{a}}\end{array}$ & $\begin{array}{r}-0.01 \\
(-0.3)\end{array}$ & $\begin{array}{c}-0.01 \\
(-2.3)^{\mathrm{a}}\end{array}$ & $\begin{array}{l}-0.01 \\
(-1.3)\end{array}$ & $\begin{array}{r}0.01 \\
(0.2)\end{array}$ & $2.0^{\mathrm{b}}$ & 0.03 \\
\hline France & $\begin{array}{c}0.05 \\
(2.0)^{\mathrm{a}}\end{array}$ & $\begin{array}{l}-0.02 \\
(-1.3)\end{array}$ & $\begin{array}{l}-0.00 \\
(-1.6)\end{array}$ & $\begin{array}{c}-0.00 \\
(-1.0)\end{array}$ & $\begin{array}{c}0.00 \\
(0.1)\end{array}$ & 1.2 & 0.01 & $\begin{array}{c}0.06 \\
(1.7)^{b}\end{array}$ & $\begin{array}{r}0.01 \\
(0.4)\end{array}$ & $\begin{array}{l}-0.00 \\
(-1.0)\end{array}$ & $\begin{array}{l}-0.00 \\
(-0.9)\end{array}$ & $\begin{array}{c}-0.01 \\
(-0.3)\end{array}$ & 0.7 & 0.00 \\
\hline Japan & $\begin{array}{c}0.10 \\
(2.5)^{a}\end{array}$ & $\begin{array}{c}-0.04 \\
(-1.5)\end{array}$ & $\begin{array}{l}-0.00 \\
(-0.8)\end{array}$ & $\begin{array}{l}-0.00 \\
(-0.6)\end{array}$ & $\begin{array}{l}-0.02 \\
(-1.2)\end{array}$ & $2.0^{\mathrm{b}}$ & 0.03 & $\begin{array}{c}0.08 \\
(2.6)^{\mathrm{a}}\end{array}$ & $\begin{array}{c}-0.00 \\
(-0.1)\end{array}$ & $\begin{array}{l}-0.00 \\
(-0.9)\end{array}$ & $\begin{array}{l}-0.00 \\
(-1.0)\end{array}$ & $\begin{array}{l}-0.02 \\
(-1.1)\end{array}$ & 1.4 & 0.01 \\
\hline South Africa & $\begin{array}{c}0.06 \\
(1.5)\end{array}$ & $\begin{array}{c}0.02 \\
(0.6)\end{array}$ & $\begin{array}{c}-0.01 \\
(-2.2)^{\mathrm{a}}\end{array}$ & $\begin{array}{c}-0.01 \\
(-2.2)^{a}\end{array}$ & $\begin{array}{r}0.02 \\
(0.9)\end{array}$ & $1.9^{\mathrm{b}}$ & 0.03 & $\begin{array}{c}0.09 \\
(2.3)^{\mathrm{a}}\end{array}$ & $\begin{array}{c}0.05 \\
(1.5)\end{array}$ & $\begin{array}{c}-0.01 \\
(-2.2)^{a}\end{array}$ & $\begin{array}{c}-0.01 \\
(-2.0)^{\mathrm{a}}\end{array}$ & $\begin{array}{c}0.00 \\
(0.0)\end{array}$ & $3.0^{\mathrm{a}}$ & 0.06 \\
\hline U.K. & $\begin{array}{c}0.06 \\
(1.8)\end{array}$ & $\begin{array}{c}-0.01 \\
(-0.4)\end{array}$ & $\begin{array}{c}-0.01 \\
(-2.2)^{\mathrm{a}}\end{array}$ & $\begin{array}{c}-0.00 \\
(-0.4)\end{array}$ & $\begin{array}{r}0.01 \\
(0.6)\end{array}$ & $1.9^{\circ}$ & 0.03 & $\begin{array}{c}0.05 \\
(1.7)^{\mathrm{h}}\end{array}$ & $\begin{array}{c}0.01 \\
(0.5)\end{array}$ & $\begin{array}{c}-0.01 \\
(-3.0)^{\mathrm{a}}\end{array}$ & $\begin{array}{l}-0.00 \\
(-0.9)\end{array}$ & $\begin{array}{c}0.02 \\
(1.6)^{\mathrm{b}}\end{array}$ & $2.7^{\mathrm{a}}$ & 0.0 \\
\hline U.S. & $\begin{array}{l}-0.00 \\
(-0.3)\end{array}$ & $\begin{array}{r}0.01 \\
(1.0)\end{array}$ & $\begin{array}{c}-0.01 \\
(-2.7)^{\mathrm{a}}\end{array}$ & $\begin{array}{c}0.00 \\
(1.3)\end{array}$ & $\begin{array}{c}0.02 \\
(2.6)^{\mathrm{a}}\end{array}$ & $4.5^{\mathrm{a}}$ & 0.10 & $\begin{array}{c}0.02 \\
(0.7)\end{array}$ & $\begin{array}{r}0.01 \\
(0.4)\end{array}$ & $\begin{array}{c}-0.01 \\
(-3.0)^{\mathrm{a}}\end{array}$ & $\begin{array}{l}-0.00 \\
(-0.3)\end{array}$ & $\begin{array}{c}0.03 \\
(2.4)^{\mathrm{a}}\end{array}$ & $2.8^{\prime \prime}$ & 0.06 \\
\hline \multicolumn{15}{|c|}{ Panel B: Hedged } \\
\hline Australia & $\begin{array}{c}0.12 \\
(2.2)^{\mathrm{a}}\end{array}$ & $\begin{array}{r}0.01 \\
(0.2)\end{array}$ & $\begin{array}{c}-0.01 \\
(-1.7)^{b}\end{array}$ & $\begin{array}{l}-0.01 \\
(-1.1)\end{array}$ & $\begin{array}{c}0.00 \\
(0.0)\end{array}$ & 1.3 & 0.01 & $\begin{array}{c}0.16 \\
(2.2)^{a}\end{array}$ & $\begin{array}{l}-0.02 \\
(-0.4)\end{array}$ & $\begin{array}{c}-0.02 \\
(-2.2)^{\mathrm{a}}\end{array}$ & $\begin{array}{l}-0.01 \\
(-1.0)\end{array}$ & $\begin{array}{r}0.01 \\
(0.3)\end{array}$ & 1.8 & 0.02 \\
\hline France & $\begin{array}{c}0.08 \\
(1.8)^{\mathrm{b}}\end{array}$ & $\begin{array}{r}-0.01 \\
(-0.4)\end{array}$ & $\begin{array}{l}-0.01 \\
(-1.1)\end{array}$ & $\begin{array}{l}-0.00 \\
(-0.6)\end{array}$ & $\begin{array}{l}-0.03 \\
(-0.1)\end{array}$ & 0.6 & 0.00 & $\begin{array}{r}0.09 \\
(1.4)\end{array}$ & $\begin{array}{c}0.02 \\
(0.4)\end{array}$ & $\begin{array}{l}-0.01 \\
(-0.7)\end{array}$ & $\begin{array}{l}-0.00 \\
(-0.5)\end{array}$ & $\begin{array}{l}-0.01 \\
(-0.2)\end{array}$ & 0.4 & 0.00 \\
\hline Japan & $\begin{array}{c}0.15 \\
(2.8)^{\mathrm{b}}\end{array}$ & $\begin{array}{c}-0.03 \\
(-0.7)\end{array}$ & $\begin{array}{l}-0.01 \\
(-0.8)\end{array}$ & $\begin{array}{r}-0.01 \\
(-0.8)\end{array}$ & $\begin{array}{l}-0.03 \\
(-1.3)\end{array}$ & 1.6 & 0.02 & $\begin{array}{c}0.13 \\
(2.5)^{\mathrm{a}}\end{array}$ & $\begin{array}{r}0.01 \\
(0.3)\end{array}$ & $\begin{array}{l}-0.00 \\
(-0.7)\end{array}$ & $\begin{array}{l}-0.01 \\
(-1.0)\end{array}$ & $\begin{array}{l}-0.03 \\
(-1.1)\end{array}$ & 1.2 & 0.01 \\
\hline South Africa & $\begin{array}{c}0.12 \\
(2.1)^{2}\end{array}$ & $\begin{array}{r}0.03 \\
(0.7)\end{array}$ & $\begin{array}{c}-0.02 \\
(-2.4)^{2}\end{array}$ & $\begin{array}{c}-0.01 \\
(-2.0)^{3}\end{array}$ & $\begin{array}{c}0.02 \\
(0.7)\end{array}$ & $2.1^{\mathrm{b}}$ & 0.04 & $\begin{array}{c}0.15 \\
(2.4)^{3}\end{array}$ & $\begin{array}{r}0.06 \\
(1.3)\end{array}$ & $\begin{array}{c}-0.02 \\
(-2.2)^{4}\end{array}$ & $\begin{array}{c}-0.01 \\
(-1.7)^{\mathrm{b}}\end{array}$ & $\begin{array}{r}0.00 \\
(0.0)\end{array}$ & $2.7^{\mathrm{a}}$ & 0.05 \\
\hline U.K. & $\begin{array}{r}0.08 \\
(1.4)\end{array}$ & $\begin{array}{r}0.02 \\
(0.5)\end{array}$ & $\begin{array}{c}-0.01 \\
(-2.3)^{\mathrm{a}}\end{array}$ & $\begin{array}{c}-0.00 \\
(-0.5)\end{array}$ & $\begin{array}{r}0.03 \\
(1.2)\end{array}$ & 1.8 & 0.03 & $\begin{array}{r}0.07 \\
(1.2)\end{array}$ & $\begin{array}{r}0.04 \\
(1.0)\end{array}$ & $\begin{array}{c}-0.02 \\
(-2.6)^{\mathrm{a}}\end{array}$ & $\begin{array}{l}-0.00 \\
(-0.7)\end{array}$ & $\begin{array}{c}0.05 \\
(1.8)^{\mathrm{b}}\end{array}$ & $2.4^{3}$ & 0.04 \\
\hline U.S. & $\begin{array}{r}0.01 \\
(0.4)\end{array}$ & $\begin{array}{r}0.02 \\
(0.7)\end{array}$ & $\begin{array}{c}-0.01 \\
(-3.0)^{2}\end{array}$ & $\begin{array}{r}0.00 \\
(-0.4)\end{array}$ & $\begin{array}{c}0.05 \\
(2.8)^{a}\end{array}$ & $3.7^{\mathrm{a}}$ & 0.08 & $\begin{array}{r}0.03 \\
(0.7)\end{array}$ & $\begin{array}{r}0.01 \\
(0.4)\end{array}$ & $\begin{array}{c}-0.01 \\
(-2.8)^{\lrcorner}\end{array}$ & $\begin{array}{r}-0.00 \\
(-0.3)\end{array}$ & $\begin{array}{c}0.05 \\
(2.4)^{\mathrm{a}}\end{array}$ & $2.5^{\mathrm{a}}$ & 0.05 \\
\hline
\end{tabular}

Degrees of freedom for the $F$-Statistic are $F(4,120)$. $t$-Statistics are in parenthesis,

asignificant at $5 \%$ level,

'Significant at $10 \%$ level.

A plausible explanation as to why U.S. economic variables better predict returns relative to own country economic variables is that the former information set includes equally weighted dividend yields. The latter information set, in comparison, uses lagged market returns as a proxy for equally weighted dividend yields since this information was unavailable in most countries. The equally weighted dividend yield does slightly better than the lag of market return in predicting asset returns because the dividend yield consists of two components - the lag of price and dividends. The lag of market returns in contrast, provides information about past performance but not about the value of stocks with respect to dividends. 
Table 8 astimation of the Latent Variable model with the rank restriction of equation imposed.

\begin{tabular}{|c|c|c|c|c|c|c|c|c|}
\hline & \multicolumn{4}{|c|}{ Unhedged Returns } & \multicolumn{4}{|c|}{ Hedged Returns } \\
\hline & \multicolumn{2}{|c|}{$\begin{array}{l}\text { Property } \\
\text { Trust }\end{array}$} & \multicolumn{2}{|c|}{ Stocks } & \multicolumn{2}{|c|}{$\begin{array}{l}\text { Property } \\
\text { Trust }\end{array}$} & \multicolumn{2}{|c|}{ Stocks } \\
\hline & $\beta_{i}$ & $\begin{array}{l}\text { Std. } \\
\text { Dev. }\end{array}$ & $\beta_{l}$ & $\begin{array}{l}\text { Std. } \\
\text { Dev. }\end{array}$ & $\beta_{i}$ & $\begin{array}{l}\text { Std. } \\
\text { Dev. }\end{array}$ & $\beta_{i}$ & $\begin{array}{l}\text { Std. } \\
\text { Dev. }\end{array}$ \\
\hline Australia & 0.08 & 0.23 & 1.43 & 0.41 & 0.90 & 0.23 & 1.17 & 0.29 \\
\hline France & 0.59 & 0.30 & 0.87 & 0.35 & 0.63 & 0.23 & 0.78 & 0.25 \\
\hline Japan & 0.55 & 0.37 & 0.14 & 0.27 & 0.26 & 0.19 & 0.36 & 0.18 \\
\hline South Africa & -0.58 & -1.00 & 1.94 & 0.64 & 0.74 & 0.35 & 1.15 & 0.37 \\
\hline U.K. & 1.20 & 0.36 & 1.45 & 0.31 & 1.18 & 0.20 & 1.23 & 0.21 \\
\hline U.S. & 1.00 & & 1.00 & & 1.00 & & 1.00 & \\
\hline$\chi^{2}$ & & 22.5 & & 20.5 & & 20.2 & & 21.5 \\
\hline Significance & & .31 & & .43 & & .45 & & .37 \\
\hline Degrees of Freedom & & 20 & & 20 & & 20 & & 20 \\
\hline EW Stocks & 1.00 & & & & 1.00 & & & \\
\hline EW Property & 0.74 & 0.11 & & & 0.90 & 0.07 & & \\
\hline$\chi^{2}$ & & 4.47 & & & & & 5.36 & \\
\hline Significance & & .35 & & & & & .25 & \\
\hline Degrees of Freedom & & 4 & & & & & 4 & \\
\hline
\end{tabular}

The null hypothesis $\left(H_{0}\right)$ is whether a one factor model explains the movement in the expected rate of returns. The alternative hypothesis $\left(H_{A}\right)$ is if more than one factor is needed to account for variations in the expected rate of return. The significance level is the level required to reject the null hypothesis e.g., a $P=.31$ means that $H_{0}$ is rejected if a $31 \%$ significance level is used. The $\mathrm{k}$-factor model that is assumed to generate asset returns is

$\tilde{r}_{i, t+1}=E_{r}\left[\tilde{r}_{i, t+1}\right]+\sum_{k=1}^{K} \beta_{i k} \tilde{f}_{k, t+1}+\tilde{\varepsilon}_{i, t+1}$

Here $\tilde{r}_{i, t+1}$ is the return on asset $i$ in excess of the riskfree rate held from time $t$ to time $t+1, E_{r}\left[\tilde{r}_{t, r+1}\right]$ is the conditional expected excess return on asset $i$ which is allowed to vary through time, $\bar{f}_{k,+1}$ are the factor realizations, $\boldsymbol{\beta}_{i k}$ are the time-invariant factor loadings and the idiosyncratic error is $\tilde{e}_{i,+1}$. If certain restrictions are imposed on this return generating model then the preceding equation can be rewritten as

$E_{t}\left[\tilde{r}_{i,+1}\right]=\sum_{k=1}^{K} \beta_{i k} \sum_{n=1}^{L} \theta_{k, n} X_{n t}=\sum_{n=1}^{L} \alpha_{i n} X_{n t}$

The combination of these two equations represent a multi-factor "Latent-Variable" model.

To formerly address the issue of market integration, Hansen's GMM methodology is used in conjunction with the asset pricing framework described in Liu and Mei (1992) to test whether a one factor model is effective in accounting for movements in the expected rate of return (the null hypothesis) and to also test whether the linear pricing relationship of an integrated world market holds. The alternative hypothesis is that a one-factor cannot capture the time-variation of risk premiums across 
different countries. The GMM results, reported in Table 8, show no evidence to reject the null hypothesis. ${ }^{19}$ Consequently, one latent factor is capable of capturing the time-variation of expected returns across different countries regardless of whether returns are hedged or unhedged. This implies that international real estate securities are integrated with international stocks. Given the findings of Tables 6, 7 and 8, it can be seen that the predicted part of the returns are extremely small and the expected returns have a tendency to move together. This is because a one factor model is capable of explaining the movement of all expected returns. However, the unanticipated part of the returns is fairly large. Consequently, the benefits of diversification come primarily from the unexpected portion of returns. These results, read in conjunction with Table 3 , imply that movements in unanticipated returns are due, in part, to changes in currency risk.

Given that international real estate securities are integrated with international stocks regardless of whether returns are hedged, the question of whether it pays to use international real estate related securities if a portfolio already includes international stocks of each country is now explored. In other words, do own country real estate related securities offer incremental risk/ return advantages to a portfolio over and above that of stocks in each country?

Figure 1 Efficient mixed asset frontiers.

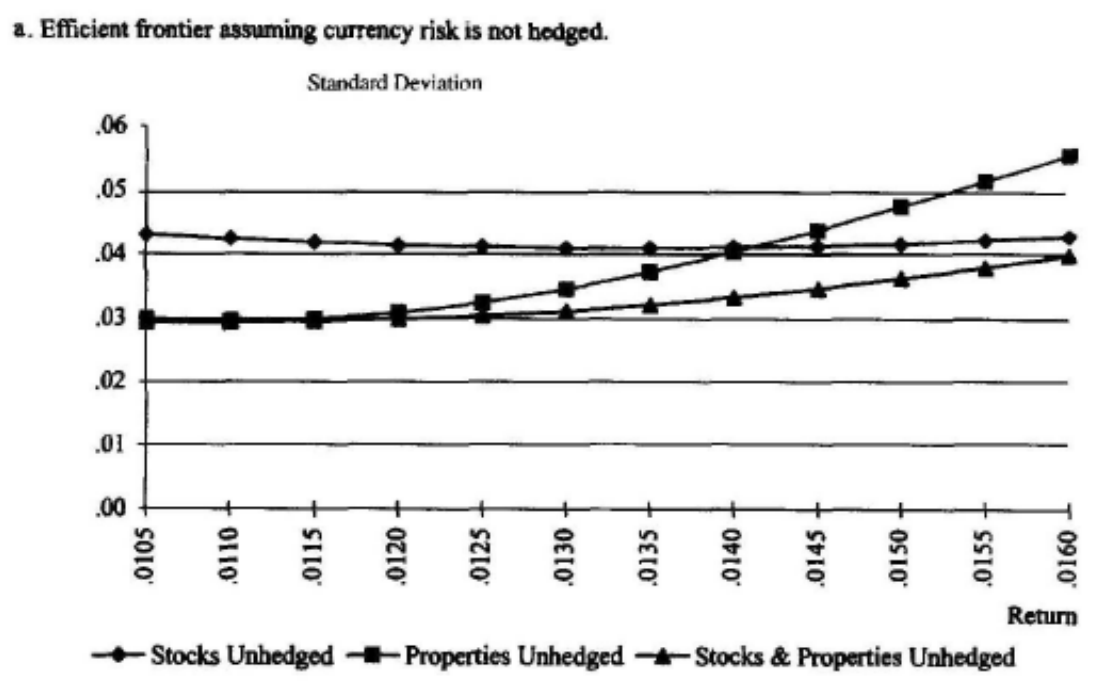

\footnotetext{
${ }^{19}$ The chi-square on the linear pricing restrictions imposed by the latent variable model in Table 8 is not significant at either the $5 \%$ or $10 \%$ level. Although the GMM test offers a more rigorous test of international market integration by imposing the restriction that the expected returns of all assets must satisfy some linear pricing restrictions, it may lack statistical power in small samples due to the fact it puts much less restrictions on the data. For example, it does not require that the residual returns follow i.i.d. normal distributions. As a result, it may be more robust but it also sacrifices the efficiency associated with the OLS tests under i.i.d. normal distributions.
} 
b. Efficient frontier assuming currency risk is hedged.

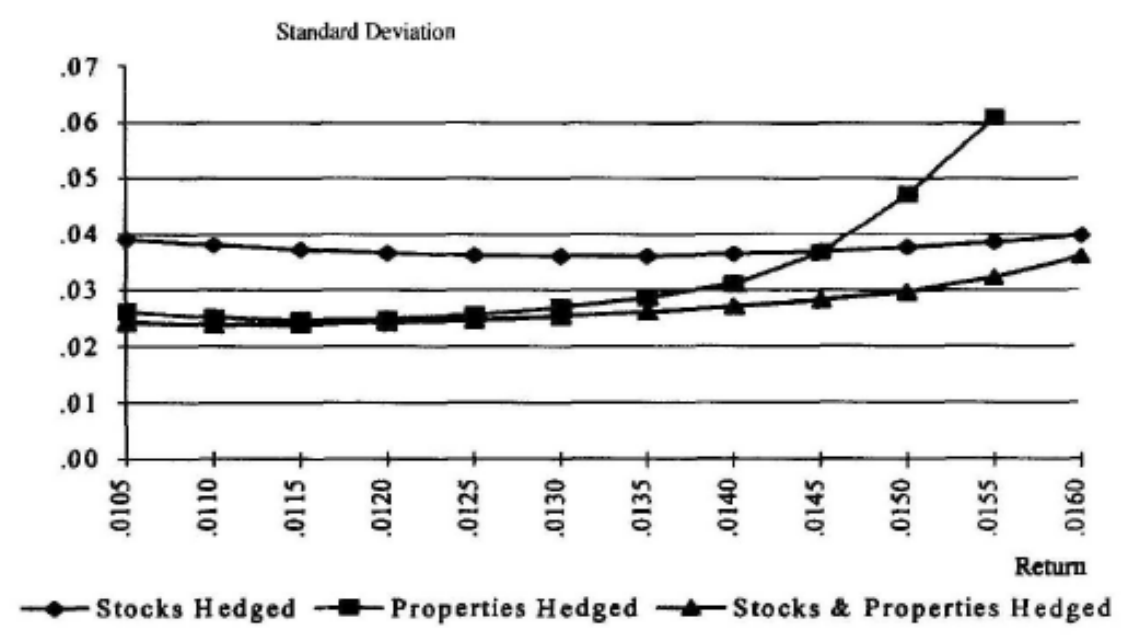

Figure 1 reports the mean-variance frontiers calculated from three sets of assets: (1) all six property trusts; (2) all six stocks; and (3) both the property trusts and the stocks assuming that returns are unhedged (Figure la) and alternatively assuming that currency risk is hedged (Figure $1 \mathrm{~b}$ ). Regardless of whether currency risk is hedged, the combination of international stock and real estate securities provides less risk at all levels of return relative to either an all real estate portfolio or a portfolio consisting only of stocks. However, the incremental reduction in risk is small at low and high levels of portfolio return. At low levels of return, the risk of an efficient, mixed asset portfolio is similar to an efficient portfolio consisting solely of international, real estate related securities. At high levels of return, the risk on an efficient, mixed asset portfolio is similar (albeit lower than) to an efficient portfolio comprised only of international stocks. Table 9 also reveals that investing in an international portfolio of stocks and real estate securities reduces the risk of a portfolio consisting solely of U.S. stocks and U.S. property trusts at all levels of return. In particular, portfolio risk is reduced between $15 \%-27 \%$ (31\%$40 \%$ ) on monthly returns of $1.1 \%-1.3 \%$ respectively, when foreign currency is not hedged (is hedged). Table 9 also shows that incremental reduction in risk is small at low levels of portfolio return because international real estate securities represent between $86 \%-88 \%$ of the efficient portfolio when the portfolio return equals $1.1 \%$ per month. Conversely, the incremental reduction in risk is also small at high levels of portfolio return since international stocks account for $71 \%-74 \%$ of the efficient portfolio when the portfolio return equals $1.6 \%$ per month. Although the aggregate inter-asset weights for real estate and stocks are similar for the efficient portfolio at low and high levels of returns regardless of whether returns are hedged, there are differences in intra-asset allocations. These differences depend on whether currency risk is hedged. U.S. real estate securities dominate efficient portfolios with low 
returns (and risk) when returns are unhedged. When returns are hedged, however, non-U.S. real estate related securities comprise the majority of the efficient portfolio at low levels of portfolio risk and return. At the highest levels of portfolio risk and return, the weight for U.S. stocks is almost equal to (but a little less than) the weight on international stocks when returns are unhedged. However, only international stocks are included in the efficient portfolio when currency risk is hedged. In fact, only international stocks and international real estate comprise the efficient portfolio if an investor hedges foreign exchange risk and desires at least a $1.6 \%$ portfolio return per month.

Table 9 a Returns, standard deviations and portfolio allocations (February 1980-March 1991).

\begin{tabular}{|c|c|c|c|c|c|c|}
\hline \multicolumn{7}{|c|}{ Panel A: Common Stocks and Property Stocks (U.S. only)* } \\
\hline Return & 0.01 & 0.01 & \multicolumn{4}{|l|}{0.01} \\
\hline Standard Deviation & 0.03 & 0.04 & \multicolumn{4}{|l|}{0.04} \\
\hline \multicolumn{7}{|l|}{ Allocations } \\
\hline U.S. Real Estate & 0.69 & 0.44 & \multicolumn{4}{|l|}{0.18} \\
\hline U.S. Stocks & 0.31 & 0.56 & \multicolumn{4}{|l|}{0.82} \\
\hline \multicolumn{7}{|c|}{ Panel B: Common Stocks and Property Stocks Unhedged } \\
\hline Return & 0.01 & 0.01 & 0.01 & 0.01 & 0.02 & 0.02 \\
\hline Standard Deviation & 0.03 & 0.03 & 0.03 & 0.03 & 0.04 & 0.04 \\
\hline \multicolumn{7}{|l|}{ Allocations } \\
\hline U.S. Real Estate & 0.60 & 0.54 & 0.42 & 0.27 & 0.12 & 0.00 \\
\hline Intl Real Estate & 0.29 & 0.29 & 0.29 & 0.29 & 0.29 & 0.26 \\
\hline U.S. Stocks & 0.05 & 0.09 & 0.16 & 0.23 & 0.31 & 0.34 \\
\hline Intl Stocks & 0.017 & 0.08 & 0.14 & 0.21 & 0.28 & 0.39 \\
\hline \multicolumn{7}{|l|}{ Aggregate Weights } \\
\hline Real Estate & 0.88 & 0.82 & 0.71 & 0.56 & $0.4 I$ & 0.26 \\
\hline Stocks & 0.12 & 0.18 & 0.29 & 0.44 & 0.59 & 0.74 \\
\hline \multicolumn{7}{|c|}{ Panel C: Common Stocks and Property Stocks Hedged } \\
\hline Return & 0.01 & 0.01 & 0.01 & 0.01 & 0.02 & 0.02 \\
\hline Standard Deviation & 0.02 & 0.02 & 0.03 & 0.03 & 0.03 & 0.04 \\
\hline \multicolumn{7}{|l|}{ Allocations } \\
\hline U.S. Real Estate & 0.30 & 0.24 & 0.17 & 0.07 & 0.00 & 0.00 \\
\hline Intl Real Estate & 0.56 & 0.59 & 0.61 & 0.61 & 0.54 & 0.29 \\
\hline U.S. Stocks & 0.00 & 0.00 & 0.05 & 0.09 & 0.06 & 0.00 \\
\hline Intl Stocks & 0.14 & 0.16 & 0.17 & 0.23 & 0.40 & 0.71 \\
\hline \multicolumn{7}{|l|}{ Aggregate Weights } \\
\hline Real Estate & 0.86 & 0.83 & 0.78 & 0.68 & 0.54 & 0.29 \\
\hline Stocks & 0.14 & 0.17 & 0.22 & 0.32 & 0.46 & 0.71 \\
\hline
\end{tabular}

Consequently, the investment implications are that if an investor is risk averse and desires a yearly portfolio return of $12 \%$ then the investor should hold a portfolio that has $86 \%-88 \%$ weight in real estate related securities and a $12 \%-14 \%$ weight in stocks to achieve the lowest risk. The intra-asset 
composition of this portfolio will depend on whether that investor wishes to hedge currency risk. If currency risk is hedged then the investor should invest primarily in international real estate securities. On the other hand, if the return is unhedged then U.S. REITs should comprise the majority of the investor's portfolio. If the investor desires higher returns, say $19 \%$ per year, then he or she should invest primarily in stocks $(71 \%-74 \%)$ with not more than $26 \%-29 \%$ in real estate securities. Furthermore, this portfolio should consist of only international assets if currency risk is hedged. Conversely, a 34\% exposure in U.S. stocks in addition to international assets is warranted if portfolio returns are unhedged. Regardless of whether currency risk is hedged however, the inclusion of international stocks and real estate securities in a portfolio does reduce the incremental risk for any given level of return relative to a portfolio consisting solely of U.S. stocks and U.S. property trusts.

While it is unlikely that any investor would hold at least $25 \%(90 \%)$ in real estate securities to obtain a $19 \%(12 \%)$ annual return, what this finding suggests is that real estate securities do provide diversification benefits. Furthermore, some real estate exposure is warranted even if the investor desires a high level of return. Another implication is that international real estate securities provide more diversification benefits relative to U.S. REITs, the higher the portfolio return if currency risk is hedged. Even if currency risk is not hedged, an investor still derives an advantage to having some exposure in foreign real estate securities.

Although it might appear from a comparison of Figure $1 \mathrm{a}$ to Figure $1 \mathrm{~b}$ that an investor benefits from hedging currency risk $^{20}$ e.g., portfolio risk is reduced, this finding ignores settlement costs and other transaction costs of the hedge. Worzala (1995) argues that if settlement costs are explicitly recognized in the hedging process, then not only will the portfolio return decrease but also the portfolio risk will increase. Thus, settlement costs might completely offset any advantage to hedging currency risk.

A finer delineation of the composition of the optimal mixed asset portfolio into the stocks and real estate securities of various countries reveals that when currency risk is not hedged, U.S. REITs comprise $60 \%$ of the efficient portfolio while French property trusts represent an additional $23 \%$ when the portfolio return desired is equal to $1.1 \%$ a month (13.2\% per year) as shown in Figure 2 a. Japanese property companies and Australian property trusts round out the real estate portion of this portfolio with weights of $4.4 \%$ and $1.4 \%$, respectively. Consequently, real estate securities comprise approximately $89 \%$ of the efficient portfolio when risk and return are relatively low and currency risk is

\footnotetext{
${ }^{20}$ This is not surprising given that the variance of unhedged returns will exceed that of hedged returns when a positive covariance exists between the return on the asset and currency returns.
} 
unhedged. The remaining $11 \%$ of the portfolio consists of stocks of the U.S. (5\%), South Africa (4\%), and Japan (2\%). Figure $2 \mathrm{~b}$ shows that when currency risk is hedged and the return on the efficient portfolio remains at $1.1 \%$ a month, the majority of the portfolio is still weighted towards real estate securities. However, French property trusts now constitute the largest portion of the optimal portfolio with a weight of $33.6 \%$ followed by U.S. and Australian property trusts with weights of $30 \%$ and $17 \%$, respectively. ${ }^{21}$ Japanese property companies round out the list of real estate related securities, representing about $5 \%$ of the efficient portfolio. The only stocks included in this portfolio are those from South Africa (12\%) and Japan (1.5\%). Thus, the real estate securities and stocks that comprise the efficient portfolio at a return of $1.1 \%$ are similar on average, albeit the weights differ, regardless of whether currency risk is hedged.

As the return on the efficient portfolio increases to $1.5 \%$ per month (18\% per year), the weights associated with property trusts/companies of various countries decrease when currency risk is not hedged. The only exception to this are French property trusts whose portfolio weight remains relatively constant at $24 \%-26 \%$. Moreover, only the real estate securities of three countries, France (26\%), U.S. $(12 \%)$ and Japan (2.6\%), remain in the efficient portfolio when the return is at $18 \%$ per year. In contrast, the weights associated with U.S. and Japanese stocks continue to increase as the risk and return on the efficient portfolio increase. In fact, U.S. and Japanese stocks dominate the portfolio (with weights of 31\% and $28 \%$, respectively) when returns reach $18 \%$ per year. At no time do South African property trusts, UK property companies, Australian stocks, French stocks or U.K. stocks enter into the efficient portfolio over this region of portfolio return.

A slightly different perspective obtains when currency risk is hedged. Both the allocation to French property trusts and Japan property companies increase, in general, until returns reach 1.5\% per month (18\% per year). South African property trusts also begin to enter into the mixed asset portfolio. In contrast, the weight given to U.S. REITs and Australian property trusts decrease as portfolio returns increase while U.K. property companies do not enter the optimal portfolio at any level of risk and return. In terms of international stocks, Japanese stocks are the dominant asset (with a weight of 59\%) in the optimal portfolio as returns exceed 1.5\%. An inverse relationship appears to exist, in general, between the weights for real estate related securities and stocks of a given country. For example, exposure to U.S. stocks increase while the weight on U.S. REITs decrease as the risk/ return on an efficient portfolio increases. Further, French stocks start to enter into the efficient portfolio only after French property

\footnotetext{
${ }^{21}$ Detailed tables on which Figure $2 \mathrm{a}$ and Figure $2 \mathrm{~b}$ are based are available from the authors.
} 
trusts exit from the portfolio. The only exception to this inverse tendency is with respect to Japanese assets. Australian stocks never enter into the efficient portfolio.

Figure 2 - Optimal portfolio of stocks and real estate.

a. Optimal portfolio of stocks and real estate assuming currency risk is not hedged.

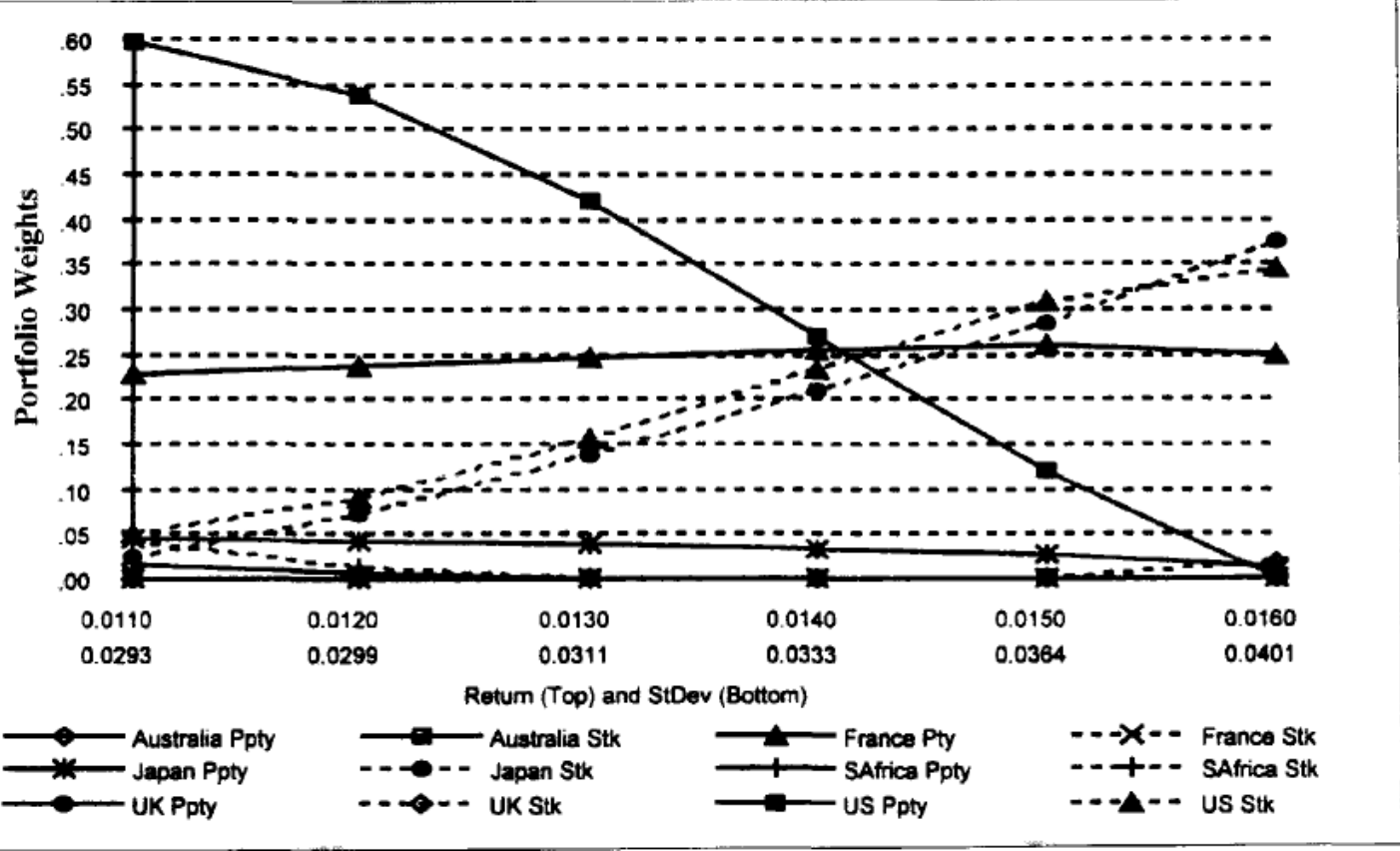

b. Optimal portolio of stocks and real estate assuming currency risk is hedged.

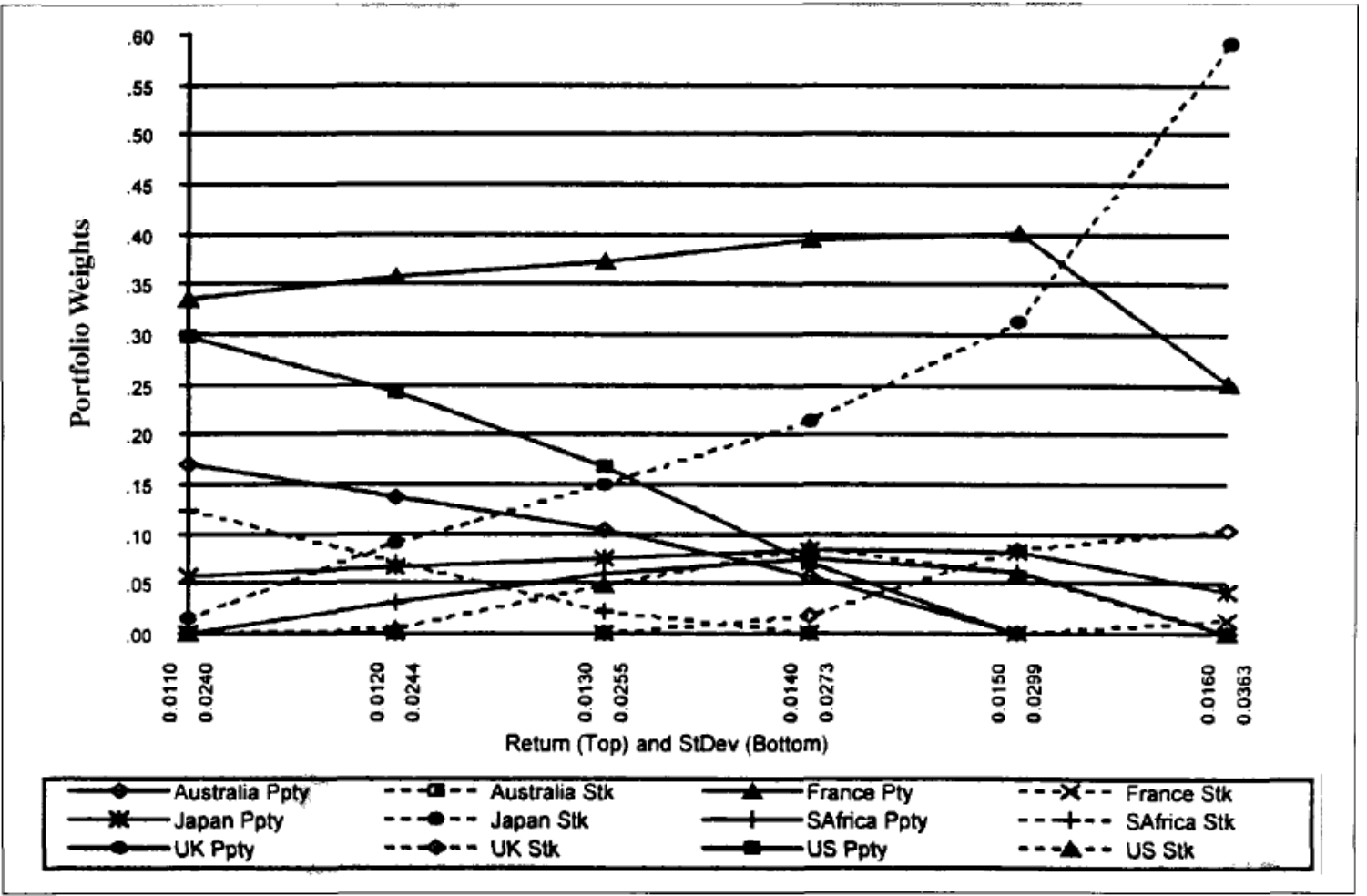


At the highest level of monthly portfolio return shown, 1.6\% (19.2\% per year), Japanese stocks represent $37 \%$ of the portfolio while U.S. stocks closely follow with a weight of $34 \%$ when currency risk is unhedged. French property trusts comprise another $25 \%$ of this portfolio while Japanese property companies (1\%) and U.K. stocks (2\%) have a minor contribution. When currency risk is hedged, Japanese stocks comprise $59 \%$ of the portfolio followed by French property trusts and U.K stocks with a $25 \%$ and $10 \%$ weight, respectively. Japanese property companies and French stocks make up the remaining assets in this portfolio.

In summary, real estate related securities from at least one country are included in the optimal mixed asset portfolio, except at extremely high levels of return when currency risk is hedged. When currency risk is not hedged, in contrast, real estate securities of South Africa and the U.K are not included in any efficient portfolio. In terms of real estate related securities included in the optimal portfolio, U.S. property trusts and French property trusts have the largest weights regardless of whether currency risk is hedged. The incremental risk/return influence of U.S. property trusts decreases while that of French property trusts increases at higher levels of portfolio risk and return. However, not all of the property securities of each country are included in an efficient portfolio. Does the fact that U.K. and Japanese property companies have different characteristics (e.g., development opportunities) relative to the rest of the real estate securities in the sample impact on the optimal portfolio? Interestingly, the results show that Japanese and U.K. property companies have a minor influence, if any, on the composition of the efficient portfolio regardless of whether currency risk is hedged. More specifically, Japanese property companies comprise $2.6 \%$ (4.4\%-5.0\%) of the optimal portfolio when portfolio returns are high (low). At no time do U.K. property companies, in contrast, enter into the efficient portfolio. These results are invariant to whether currency risks are hedged.

\section{Conclusion}

This study examines the extent to which returns on stocks and real estate related securities are predictable in six countries in an attempt to discover which portion of the return is responsible for international diversification benefits. Both a hedged strategy for exchange rate risk and an alternative unhedged strategy are considered. A group of own country economic variables and a set of U.S. economic variables are alternatively used as the relevant information set to predict hedged and unhedged returns. The predicted portion of the returns on both stocks and real estate securities are small and tend to move in tandem. This common co-movement of expected returns arises because these capital markets are integrated and a one-factor model is sufficient in capturing the time-variation 
of risk premiums across different countries. Further, regardless of which information set is used, the expected portion of returns for portfolios consisting of both unhedged and hedged returns are quite small. This suggests that diversification benefits arise primarily from the unexpected portion of returns. Changes in currency risk account, in part, for movements in unanticipated returns. The most distinguishing result is the finding that investing in international real estate related securities provides additional (incremental) diversification benefits over and above that associated with international stocks. These benefits are relatively more pronounced at lower risk-return levels of the optimal portfolio and are present regardless of whether currency risks are hedged. Thus, U.S. investors should consider including international real estate securities in their portfolios.

It is worth noting that the results are based on historical returns from the sample period of 1980-1991. The optimal portfolio weights derived here, therefore, may not be applicable to future asset allocations if the underlying economic conditions have changed. However, this study has at least demonstrated the benefits of international diversification and the role of real estate securities. Furthermore, the approaches developed are certainly useful for portfolio managers in solving their asset allocation problems.

\section{References}

Adler, M. and B. Dumas. 1983. International Portfolio Choice and Corporation Finance: A Synthesis. Journal of Finance 38(3): 925-984.

Asabere, P., R. Kleiman and C. McGowan Jr. 1991. The Risk-Return Attributes of International Real Estate Equities. Journal of Real Estate Research 6(2): 143-152.

Campbell, J.Y. 1987. Stock Returns and the Term Structure. Journal of Financial Economics 18(2): $373-$ 399.

1993. Intertemporal Asset Pricing Without Consumption. American Economic Review 83(3): 487-512.

Campbell, J.Y. and Y. Hamao. 1992. Predictable Stock Returns in the United States and Japan: A Study of Long-Term Capital Market Integration. Journal of Finance 47(1): 43-70.

Chen, N., R. Roll and S. Ross. 1986. Economic Forces and the Stock Market. Journal of Business 59(3): 386-403.

Connor, G. and R.A. Korajczyk. 1988. Risk and Return in an Equilibrium APT: Application of a New Test Methodology. Journal of Financial Economics 21(2): 255-289. 
Eun, C. and B. Resnick. 1988. Exchange Rate and Uncertainty, Forward Contracts, and International Portfolio Selection. Journal of Finance 43(1): 197-215.

Errunza, V. and E. Losq. 1985. International Asset Pricing under Mild Segmentation: Theory and Test. Journal of Finance 40(1): 105-124.

Fama, E. and K. French. 1988. Dividend Yields and Expected Stock Returns. Journal of Financial Economics 22(1): 3-25.

1989. Business Conditions and Expected Return on Stocks and Bonds. Journal of Financial Economics 25(1): 23-49.

Fama, E. and G.W. Schwert. 1977. Asset Returns and Inflation. Journal of Financial Economics 5(2): 115146.

Ferson, W. 1989. Changes in Expected Security Returns, Risk, and Level of Interest Rates. Journal of Finance 44(5): 1191-1217.

Ferson, W. and C. Harvey. 1991. The Variation of Economic Risk Premiums. Journal of Political Economy 99(2): 385-415.

Ferson, W., S. Kandel and R. Stambaugh. 1987. Test of Asset Pricing with Time- Varying Expected Risk Premiums and Market Betas. Journal of Finance 42(2): 201-219.

Frenkel, J. and R. Levich. 1977. Transactions Cost and Interest Arbitrage: Tranquil versus Turbulent Periods. Journal of Political Economy 85(6): 1209-1226.

Gibbons, M.R. and W. Ferson. 1985. Testing Asset Pricing Models with Changing Expectations and an Unobservable Market Portfolio. Journal of Financial Economics 14(2): 217-236.

Hauser, S., M. Matityahu and U. Yaari. 1994. Investing in Emerging Stock Markets: Is It Worthwhile Hedging Foreigh Exchange Risk? Journal of Portfolio Management 20(3): 76-81.

Jorion, P. and E. Schwartz. 1986. Integration versus Segmentation in the Canadian Stock Market. Journal of Finance 41(3): 603-616.

Keim, D.B. and R. Stambaugh. 1986. Predicting Returns in the Stock and Bond Markets. Journal of Financial Economics 17(2): 357-390.

Liu, C.H. and J. Mei. 1992. The Predictability of Returns on Equity REITs and Their Co-movement with Other Assets. Journal of Real Estate Finance and Economics 5(4): 401-418. 1994. An Analysis of Real Estate Risk Using the Present Value Model. Journal of Real Estate Finance and Economics 8(1): 5-20.

Malkiel, B. 1990. A Random Walk Down Wall Street. 5th Edition. W.W. Norton: New York. 
Mei, J. and A. Saunders. 1995. Have U.S. Financial Institutions' Real Estate Investments Exhibited 'TrendChasing' Behavior? Review of Economics and Statistics.

Miles, M., B. Webb and D. Guilkey. 1991. On the Nature of Systematic Risk in Commercial Real Estate. Working Paper \#467. Indiana University: Bloomington, IN.

Ross, S. 1976. The Arbitrage Theory of Capital Asset Pricing. Journal of Economic Theory 13(3): 341-360.

Stehle, R. 1977. An Empirical Test of the Alternative Hypotheses of National and International Pricing of Risky Assets. Journal of Finance 32(2): 493-502.

Worzala, E. 1995. Currency Risk and International Property Investments. Journal of Property Valuation and Investment 13: 23-38.

Ziobrowski, A. and R. Curcio. 1991. Diversification Benefits of U.S. Real Estate to Foreign Investors. Journal of Real Estate Research 6(2): 119-142.

\section{Appendix}

\section{Detailed Description of the Latent Variable Model}

Basically, the asset pricing framework used in this study is identical to that of Liu and Mei (1992) and assumes that the following K-factor model generates asset returns:

(A.1) $\tilde{r}_{i, t+1}=E_{t}\left[\tilde{r}_{i, t+1}\right]+\sum_{k=1}^{k} \beta_{i k} \bar{f}_{k, t+1}+\tilde{\varepsilon}_{i, t+1}$

Here $\tilde{r}_{i, t+1}$ is the return on asset $i$ in excess of the riskfree rate held from time $t$ to time $t+1, E_{t}\left[\tilde{r}_{i, t+1}\right]$ is the conditional expected excess return on asset $i$ which is allowed to vary through time, ${ }^{22} \bar{f}_{k, t+1}$ are the factor realizations, $\beta_{i k}$ are the time-invariant factor loadings and the idiosyncratic error is $\tilde{e}_{i, t+1}$. If certain restrictions are imposed on this return generating model then Equation (A.1) is rewritten as: ${ }^{23}$ (A.2) $E_{t}\left[\tilde{r}_{i, t+1}\right]=\sum_{k=1}^{k} \beta_{i k} \sum_{n=1}^{L} \alpha_{i n} X_{n t}$

\footnotetext{
${ }^{22}$ Evidence on time-varying risk premiums is reported in Campbell (1987), Fama and French (1989) and Ferson, Kandel and Stambaugh (1987), among others.

${ }^{23}$ These restrictions are that (1) the conditional expected rate of return is a linear function of the factor risk premiums, with the coefficients equal to the betas of each asset or mathematically:

$E_{t}\left[\tilde{r}_{i, t+1}\right]=\sum_{k=1}^{k} \beta_{i k} \lambda_{k t}$

where $\lambda_{k t}$ is the "market price of risk" for the $k^{\text {th }}$ factor at time $t$. There are a number of intertemporal asset pricing models which can generate this type of linear pricing relationship, under either a no arbitrage opportunity condition or through a general equilibrium framework (see, for example, Ross 1976; Campbell 1993; and Connor and Korajczyk 1988), and (2) the conditional expectations are a linear function of $L$ forecasting variables $X_{n t}$, $\mathrm{n}=1, \ldots, \mathrm{L}$ (where $\mathrm{X}_{1 \mathrm{t}}$ is a constant) which represent the information set at time $t$, so $\lambda_{k t}$ is written as
} 
The combination of Equations (A.1) and (A.2) represent a multi-factor "latent-variable" model. ${ }^{24}$ The model implies that expected excess returns are time-varying and can be predicted by the forecasting variables $\left(X_{n t}\right)$ in the information set. The forecasting variables used are the common, economic state variables discussed earlier. ${ }^{25}$ The model puts some restrictions on the coefficients of Equation (A.2), namely

(A.3) $\alpha_{i j}=\sum_{k=1}^{K} \beta_{i k} \theta_{k j}$

Here, $\beta_{i k}$ and $\theta_{k j}$ are free parameters. To test the restriction in Equation (A.3), the model is first renormalized by setting the factor loadings of the first $K$ assets as follows: $\beta_{i j}=1$ (if $j=i$ ) and $\beta_{i j}=0$ (if $j \neq i$ ) for $1 \leq i \leq K$. If the linear pricing relationship holds, that implies that the data should not be able to reject the null hypothesis of Equation (A.3) $H_{0}: \sigma=\Theta B$ in the following regression in Equation (A.4),

$$
\text { (A.4) } R_{1}=X \Theta+\mu_{1} \quad R_{2}=X \alpha+\mu_{2}
$$

where $B$ is a matrix of $\beta_{i j}$ elements and $R=\left(R_{1} R_{2}\right)$ is the excess returns matrix. Here $R_{1}$ is a TxK matrix of excess returns of the first $K$ assets and $R_{2}$ is a $T x(N-K)$ matrix of excess returns on the rest of the assets. The regression system in Equation (A.4) is used to see to what extent the forecasting variables, $X$, predict excess returns of all assets and to test the linear pricing restriction of Equation (A.3). If the linear pricing restriction is not rejected by the data, then there is evidence of market integration, since the variations in asset expected returns can be explained by the variation of some systematic factors, $f_{k, t+1}$.

The regression system of Equation (A.4), given the restriction in Equation (A.3), is estimated and tested using Hansen's GMM. A chi-square test is performed to see if the data rejects the restricted regression system in Equation (A.4).

$\lambda_{k t}=\sum_{n=1}^{k} \Theta_{k n} X_{n t}$

${ }^{24}$ For more details on this model, see Gibbons and Ferson (1985), Campbell (1987) and Ferson and Harvey (1990).

${ }^{25}$ Keim and Stambaugh (1986), Campbell (1987), Fama and French $(1988,1989)$, Ferson (1989), Ferson and Harvey (1990), Campbell and Hamao $(1992)$ and Liu and Mei $(1992,1994)$ have used these variables among others. Fama and French (1989) also uses the spread between yields of a low grade long-term corporate bond and a long-term treasury bond to capture the default risk in the financial market. But they find the variable to be capturing the same information as the dividend yield. Thus, only dividend yield is included here. 